Volume 12, Issue 2 (Summer 2020)

\title{
A Mirror for the Prince? Anne of Denmark in Hunting Costume with Her Dogs (1617) by Paul van Somer
}

Sara Ayres

ayressara@hotmail.com

Recommended Citation:

Sara Ayres, "A Mirror for the Prince? Anne of Denmark in Hunting Costume with Her Dogs (1617) by Paul van Somer," Journal of Historians of Netherlandish Art 12:2 (Summer 2020) DOI: 10.5092/ jhna.12.2.2

Available at https://jhna.org/articles/a-mirror-for-the-prince-anne-of-denmark-in-hunting-costume-with-her-dogs-1617-by-paul-van-somer

Published by Historians of Netherlandish Art: https://hnanews.org/

Republication Guidelines: https://jhna.org/republication-guidelines/

Notes: This PDF is provided for reference purposes only and may not contain all the functionality or features of the original, online publication. This PDF provides paragraph numbers as well as page numbers for citation purposes.

ISSN: 1949-9833 
JOURNAL OF HISTORIANS OF NETHERLANDISH ART

\section{A Mirror for the Prince? Anne of Denmark in Hunting Costume with Her Dogs (1617) by Paul van Somer}

Sara Ayres

This essay reassesses a portrait of Anna of Denmark, Queen Consort to James VI and I, discussing its possible influence upon and use by her son, Charles, Prince of Wales, as an exemplary pattern of majesty. The portrait's aesthetic references to Anna's venerable genealogy and issue, alongside its singular originality, present the queen as a work of art wrought from the rarest dynastic materials and aesthetic precedents. It suggests that, in tandem with its function as a representation of the queen's own majesty, the portrait acts within a semiprivate dynastic-familial context, as a mirror for the prince and as a connoisseurial model of martial majesty for his emulation.

This essay re-examines the emblematic portrait Anne of Denmark in Hunting Costume with her Dogs by Paul van Somer (fig. 1). ${ }^{1}$ The portrait of the queen consort of James VI and I, King of Great Britain and Ireland, was painted in the sitter's early forties, when she was the mother of seven children, two of whom had survived into adulthood. Only one of those children remained in England: her son, Charles, then Prince of Wales, the future Charles I of England.

The portrait was paid for, and presumably commissioned, by Anna herself. ${ }^{2}$ During her lifetime, the portrait was displayed at Oatlands Palace, one of her residences. The portrait's display within the context of Oatlands Palace has been the subject of recent articles by Jemma Field and Wendy Hitchmough. Both discuss not only the portrait's iconography in relation to wider court politics but also its choreography at Oatlands in relation to other works of art in the palace's evolving collections. ${ }^{3}$ A few days after Anna's death, the work was sent to Prince Charles's court at St. James Palace. ${ }^{4}$ Whether this move honored the wishes of the dying Queen or those of her son remains unknown. This essay considers the significance of the portrait's posthumous presence at St. James Palace; the nature of its specific, intra-dynastic address to the new Prince of Wales; and his response to its stimulus within a semiprivate familial context of cultural transfer and dynastic succession. 


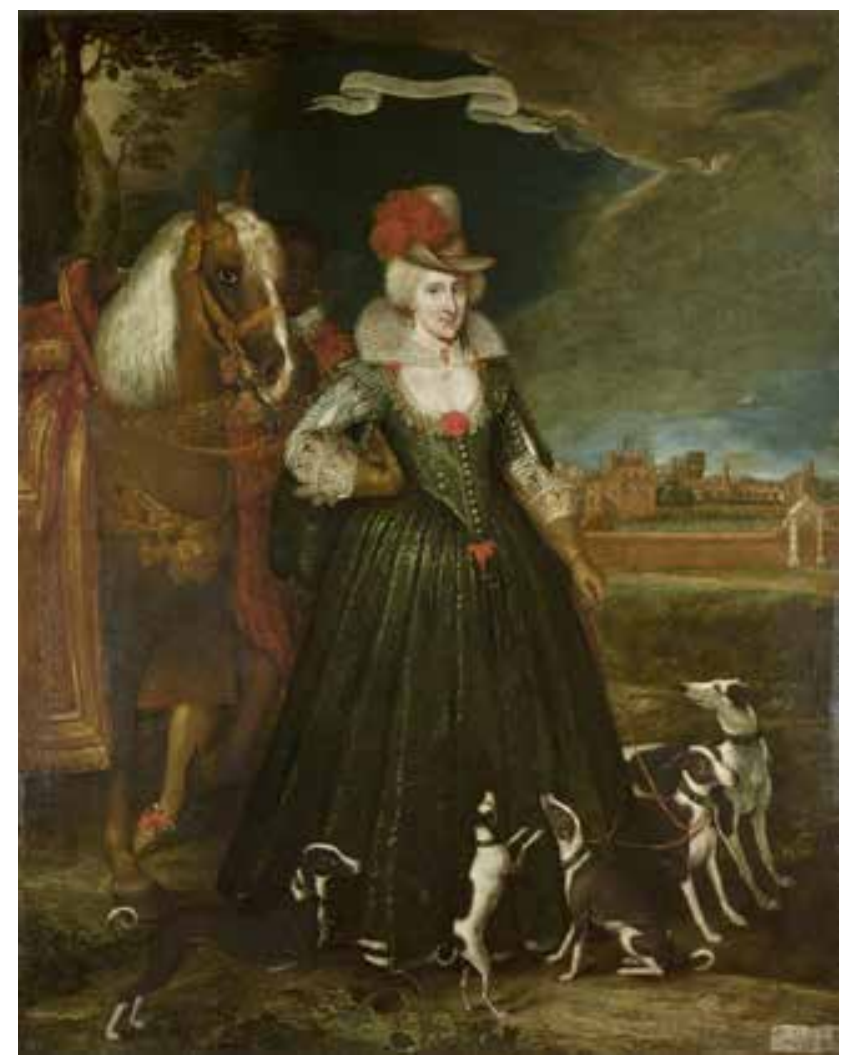

Fig. 1 Paul van Somer, Anne of Denmark, signed and dated 1617, oil on canvas, $265.5 \times 209.0 \mathrm{~cm}$. Royal Collection Trust / @ Her Majesty Queen Elizabeth II 2020 London, RCIN 405887

In what follows, I will demonstrate that the portrait exemplifies early modern elite self-fashioning as an act of creative originality, drawing on the same methods and principles as a highly trained artist creating a new work of art. Within the portrait, the stuff of Anna's venerable genealogy is shaped and molded by the agency of her individuality. Anna's portrait wittily presents her as an artwork of her own creation whose sitter has used her innate, God-given qualities-infused from on high, as her motto reminds us-to fashion the material inherited from her dynastic forebears. Practices of self-fashioning, based on erudition and creativity, allied to a virtuous genealogy, shadow the construction of this exemplary royal portrait, which, I will argue, quite literally impressed a future King. Anna's aware complicity in this directed "impression" is signaled by her appropriation of the masculine pose of hand on hip and the commanding position she assumes on the hunting field.

\section{Gender and Genealogy}

The body of the consort as staged in her portraits-from betrothal portraits proclaiming her as a potential ornament to her marital court, to the effigies enacting royal funeral rites-always answered political imperatives. The image of the consort, shining with brilliants and garlanded with offspring, personified a pledge of prosperous continuity to the greater political body whose head was the wise ruler. While the primary duty of a royal consort was the reproduction in flesh and blood of the dual royal dynasties to which she belonged, the reiterative force of picturing these children in other media multiplied the visible might and majesty of her marital court. Portraits of consorts and the heirs, spares, and princesses they brought forth served important domestic and diplomatic purposes. As Catriona Murray has shown, royal children, when they arrived and even when they died, were replicated in portraits painted, printed, and cast. ${ }^{6}$ Anna's portrait innovates 
from within this practice, functioning both as a screen for the external projection of the aura of dynastic majesty emitted by the reign of James VI and I and, more narrowly, as a mirror for her son, the future Charles I.

As such, Anne of Denmark both conforms to and departs from the conventions of the female consort portrait. It departs from these, first, in terms of its subject's depiction while engaged in the courtly hunt. Anna wears green hunting garb, her physical stature raised by her high hat, embellished with a red feather trim. She is accompanied by a horse and a black groomsman wearing the Oldenburg family colors of red and gold. Her left hand grips the leash of a brace of two black-and-white greyhounds, while three wait unleashed at her feet. Her right hand is turned back and rests upon her hip, her elbow forming a jutting point. Anna is presented in the hunting landscape of Oatlands Palace. Its park wall features a gateway designed by the architect Inigo Jones, completed early in 1617. The specific, recognizable setting, unique among Anna's portraits, shimmers under a sky dramatically split between darkness and daylight, as if to highlight the analogical relationship between the microcosm and the macrocosm, the earthly and the divine, so central to the period's habits of thought.

An owl, the bird of Minerva, who, as goddess of wisdom and war, governed princely pedagogy, lurks flatly in the tree at the left. The groom, wearing the colors of the House of Oldenburg, creates a self-contained, satellite presence within the portrait; he looks at the Queen, modeling the serious regard expected of us as viewers. The bridled horse, richly caparisoned in red and gold, delicately raises one hoof and engages the spectator's gaze. A deer runs alongside the palace wall. The dogs seem ready to set off into the bracken, and they wear collars emblazoned with Anna’s cipher. Anna’s motto, "La Mia Grandezza Dal Eccelso" (my greatness comes from on high) unfurls over the scene.

Anne of Denmark is often described as a splendid costume portrait. Yet this fails to recognize the painting's singularity. The Queen does more than merely model her hunting garb. Her firm grasp of the dogs' leash asserts her right to deploy the weapons of the field herself. Her jutting elbow signifies a status that is masculine and martial, and this forms the second departure from the normative conventions of consort imagery. If the female elbow akimbo is a signifier of a woman exceeding the limits of her gender, if she is figuratively elbowing those limits aside, then this is amplified in Anna's portrait by her participation in the hunt, an activity performative of aristocratic masculinity via its use as training for war.

It should be stated that there is ample evidence that women of the period, including members of the dynastic and political networks surrounding Anna, participated in the hunt. ${ }^{8}$ Anna's brother, Christian IV, King of Denmark, wrote in his diary for September 13, 1607, that the cloak of his wife, Anna of Brandenburg, had been shot through while she was out hunting. ${ }^{9}$ In a 1605 missive to the Earl of Salisbury, the Earl of Shrewsbury gleefully reported: "My wife has sent you four pies of red deer . . . being of a stag that had the mishap to be killed by her own hand." ${ }^{10}$ While hunting deer in July 1613, Anna of Denmark mistakenly shot James's favourite hound, Jewel. As John Chamberlain related: "After he knew who did it, he was soon pacified, and with much kindness wished her not to be troubled with it, for he should love her never the worse; and the next day sent her a diamond worth $£ 2000$ as a legacy from his dead dog." ${ }^{11}$ It is certainly the case that Anna 
kept greyhounds during 1617. In two letters dated March and April of that year, Thomas Watson wrote that two greyhounds he had seized for catching a hare had proven to be the Queen's. His fears that he might be punished for this were unfounded, for the Queen sent to say if he found any more he should simply return them to her. ${ }^{12}$

It may be that arguments suggesting that women spectated, but did not (usually) participate actively in the hunt are overdetermined by surviving images of the hunt, most of which show male hunters. Yet intriguing portraits of royal female hunters also survive, as a recent exhibition at Schloss Ambras has demonstrated in relation to Maria of Portugal and Maria of Hungary. ${ }^{13}$ We might also include the possible portrayal of Elisabeth of Lorraine hunting in the monumental Months of the Year tapestry series (especially April, July, and November), woven by Hans van der Biest to designs by Peter Candid just a few years before Anna's portrait was painted by van Somer (figs. 2, 3, 4) ${ }^{14}$ Further, Elizabeth I is represented as a huntress in woodcuts illustrating The Noble Arte of Venerie of 1575. This shows George Gascoigne, the translator of the work, presenting

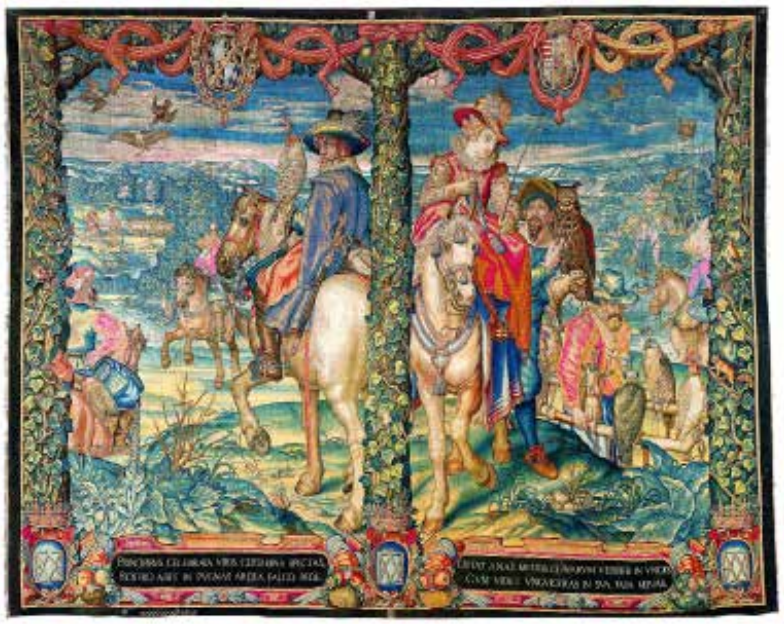

Fig. 2 Hans van der Biest after a design by Pieter de Witte, April tapestry from the Months of the Year series, 1612-14, silk, wool, and metal thread, 407-10 x 523-28 cm. Residenz, Munich, Inv.-Nr. BSV.WA 38. ( Bayerische Schlösserverwaltung Maria Scherf/Andrea Gruber, München

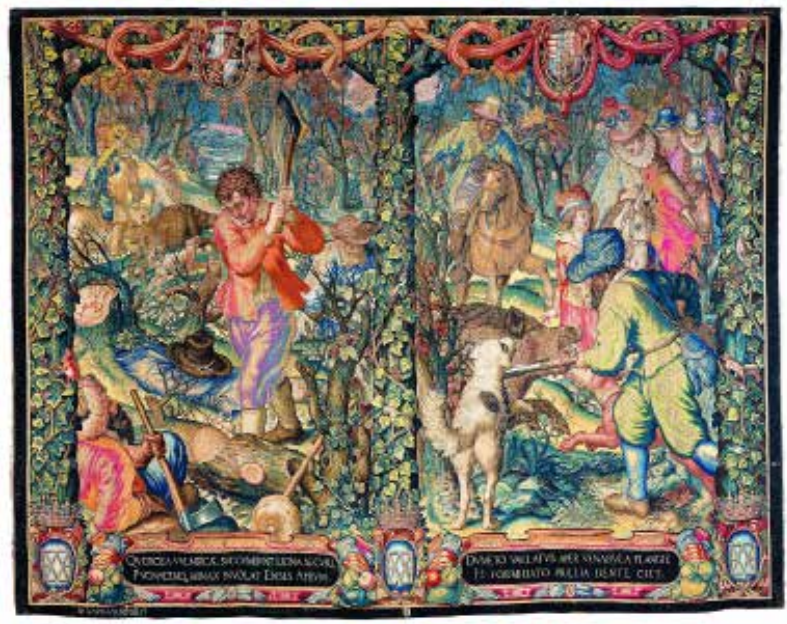

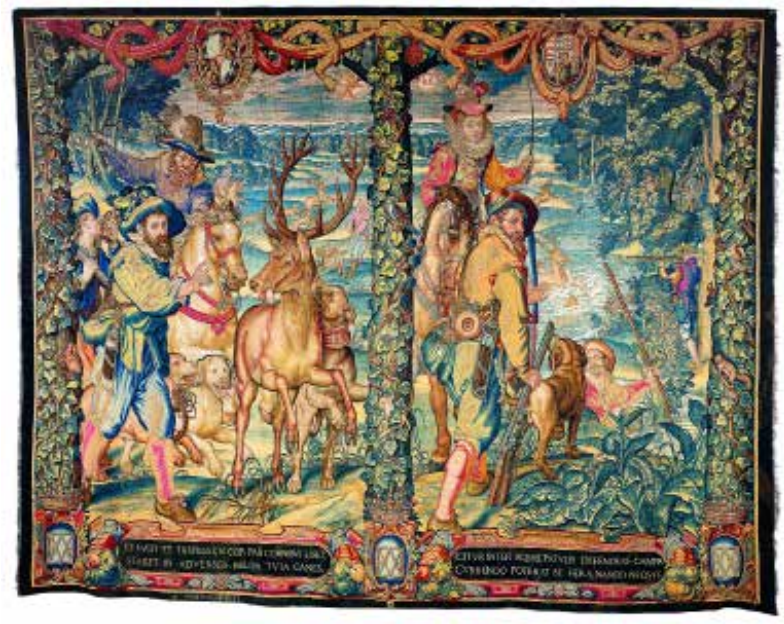

Fig. 3 Hans van der Biest after a design by Pieter de Witte, July tapestry from the Months of the Year series, 1612-14, silk, wool, and metal thread, 408-9 x 525-30 cm. Residenz, Munich, Inv.-Nr. BSV.WA0041. () Bayerische Schlösserverwaltung Maria Scherf/Andrea Gruber, München

Fig. 4 Hans van der Biest after a design by Pieter de Witte, November tapestry from the Months of the Year series, 1612-14, silk, wool and metal thread, $409 \times 524-28 \mathrm{~cm}$. Residenz, Munich, Inv.-Nr. BSV.WA 45. @ Bayerische Schlösserverwaltung Maria Scherf/Andrea Gruber, München 
Queen Elizabeth with a knife to commence the undoing of the quarry, her privilege as the most senior figure attending a par force ("by strength of dogs") hunt. Following the succession, Elizabeth's image was replaced with one of James VI and I. ${ }^{15}$ No official portrait depicts Elizabeth in the act of hunting, although her iconography draws on that of Diana, the virgin Roman goddess of the hunt, and she is reported to have enjoyed the sport. ${ }^{16}$ The Devonshire Hunt tapestries, originating two centuries before Anna's portrait, would have been known within the architectonic context of their contemporary display at Hardwicke Hall and consequently in relation to the identity of the Countess of Shrewsbury, "Bess of Hardwicke." Her granddaughter, Arbella Stuart, was cousin to James VI and I and a close friend of Anna's, performing in her masques. ${ }^{17}$ Peter Paul Rubens's Wolf and Fox Hunt (ca. 1616) - a picture that the English ambassador to the Hague, Sir Dudley Carleton, attempted yet failed to buy in 1616-17-includes a composed female huntress, albeit at the periphery of the battle (fig. 5). ${ }^{18}$ Equipped female bodies actively participating in hunting appear frequently in representations of myths, such as in the Histories of Diana tapestry series, designed by Karel van Mander and woven by Francois Spiering in Delft, elements of which survive in English collections (figs. 6 and 7). ${ }^{19}$

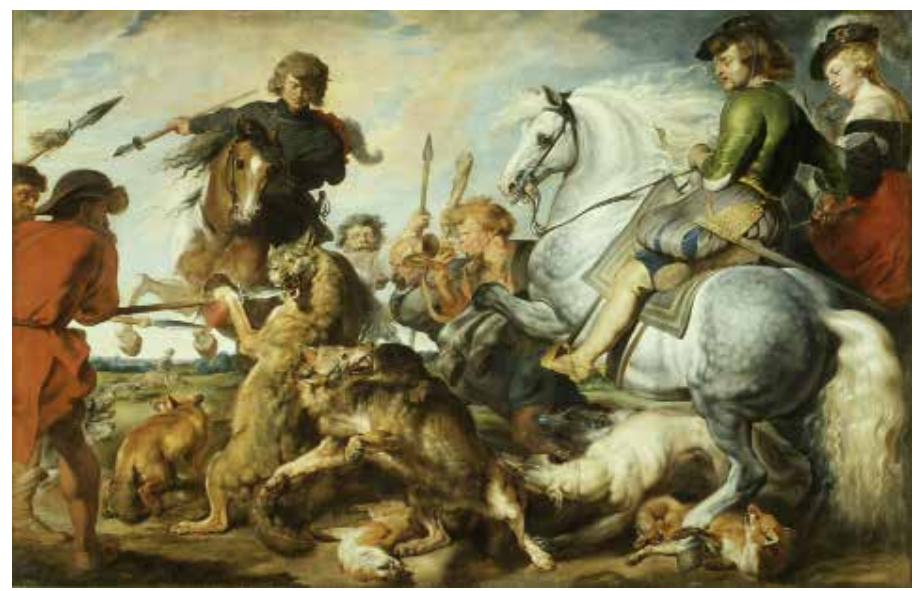

Fig. 5 Peter Paul Rubens, Wolf and Fox Hunt, ca. 1616, oil on canvas, $245.4 \times 376.2 \mathrm{~cm}$, Metropolitan Museum of Art, New York, John Stewart Kennedy Fund, 1910 (10.73) Image courtesy the Metropolitan Museum of Art (artwork in the public domain)

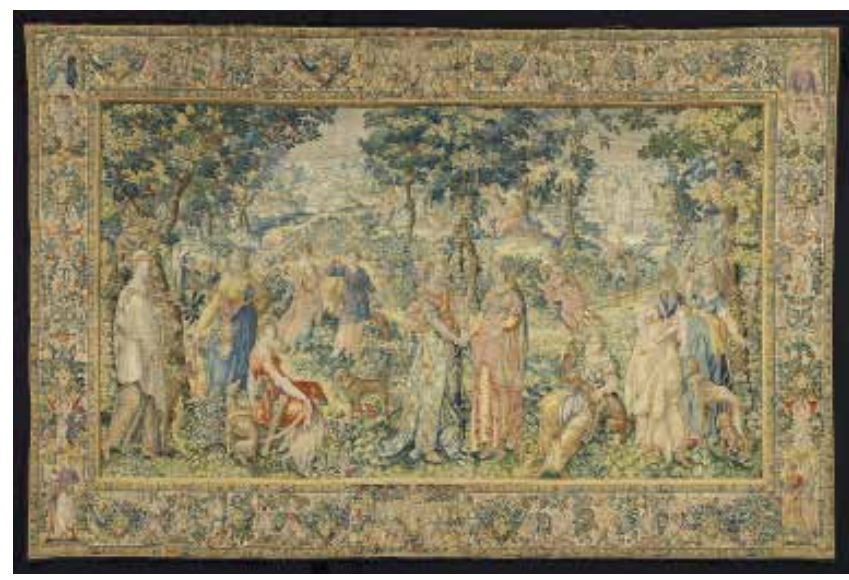

Fig. 6 Attributed to Karel van Mander (design), François Spierinx (maker), Cephalus and Procris tapestry from the Histories of Diana series (ca. 1593-1610), wool and silk on a woolen weft, 354 (left)-351 (right) x 546 (upper)-542 (lower) cm. Rijksmuseum, Amsterdam, BK-1954-69-B (artwork in the public domain)

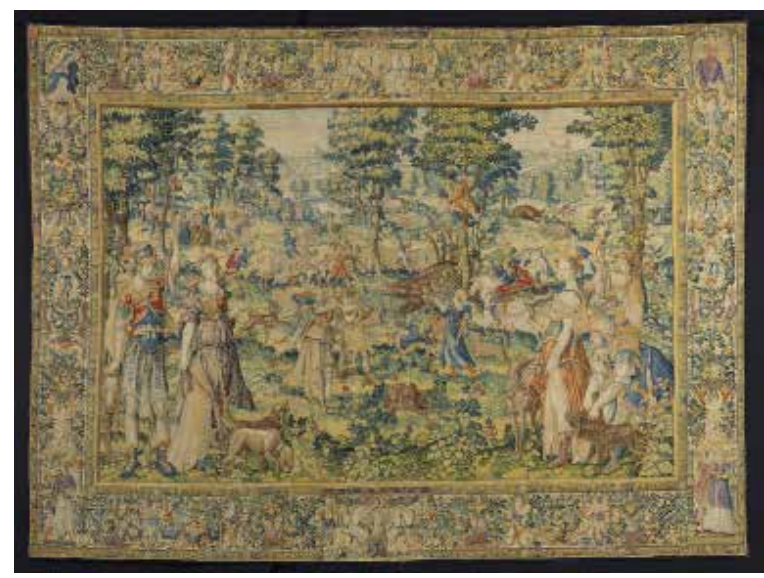

Fig. 7 Attributed to Karel van Mander (design), François Spierinx (maker), Meleager and Atalanta tapestry from the Histories of Diana series, ca. 1593-1600, wool and silk on a woolen weft, 351 (left)-347 (right) x 469 (upper)-468 (lower) cm. Rijksmuseum, Amsterdam, BK-2006-77 (artwork in the public domain) 
Notwithstanding such a rich array of precedents, the hunting theme of van Somer's portrait has been explained as a means of visually binding the image to existing portraits by Robert Peake the Elder of Anna's deceased son and only surviving daughter: Henry Frederick (1594-1612), Prince of Wales, with Sir John Harington (1592-1614), in the Hunting Field of 1603 and Princess Elizabeth (1596-1662), aged Seven, also 1603 (figs. 8 and 9). ${ }^{20}$ The assumption that Anna's portrait would have been received primarily in association with her children's portraits conforms to the traditional historiographical expectations of consort imagery. Such expectations render the hunting landscape setting specific to these precedents and foreground Anna's successful motherhood. The narrative continuity embedded in their hunting landscape settings (which, in the case of Peake's pendants, is also an aesthetic-topographical continuity, connecting the portraits of brother and sister) may indeed speak to an intent to link Anna's portrait with those of her issue, situating her identity within a chain of family resemblances. The continuity of English green complements the genealogical colors ordinarily constituted by the coat of arms, bodied forth in Anna's portrait by the groom and her horse.

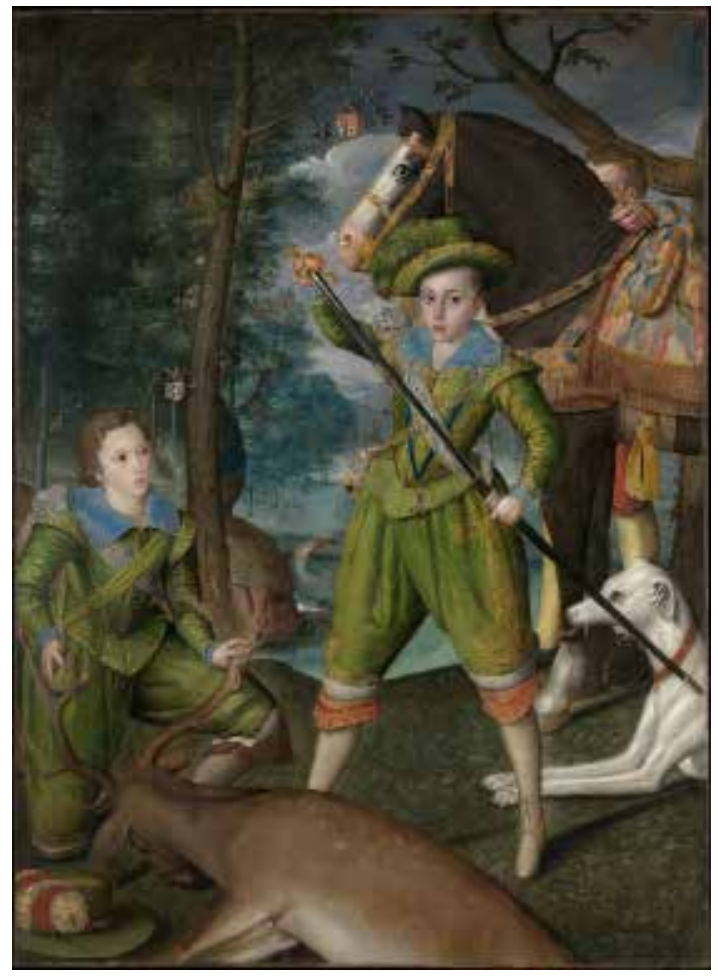

Fig. 8 Robert Peake the Elder, Henry Frederick Prince of Wales, with Sir John Harington in the Hunting Field, 1603, oil on canvas, 201.9 x 147.3 $\mathrm{cm}$, Metropolitan Museum of Art, New York, Purchase, Joseph Pulitzer Bequest, 1944 (44.27) Image courtesy the Metropolitan Museum of Art

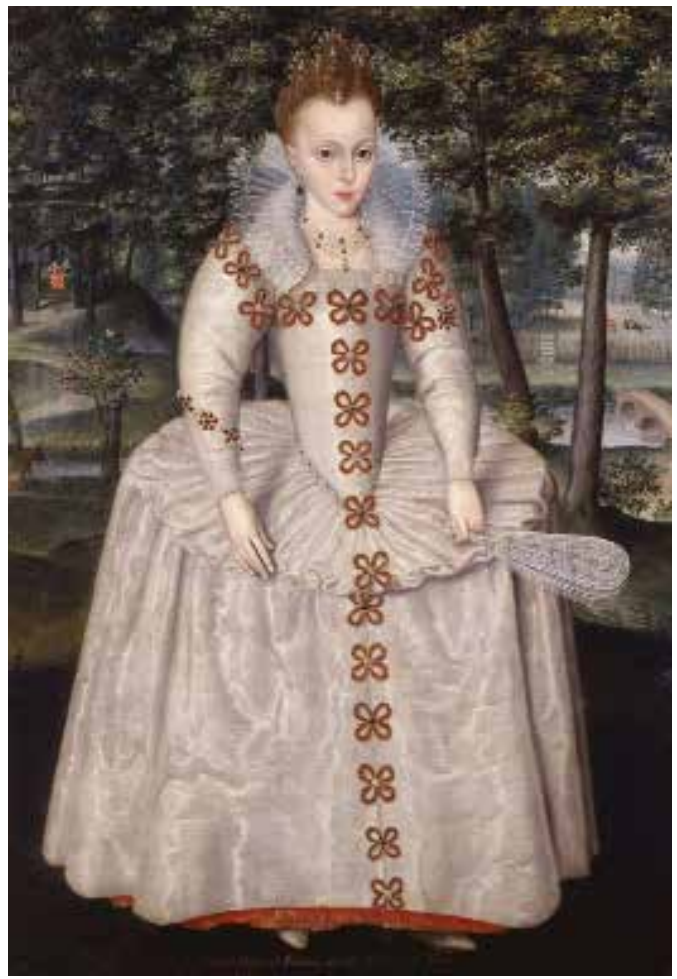

Fig. 9 Robert Peake the Elder, Princess Elizabeth, 1603, oil on canvas, $135.9 \mathrm{~cm} \times 95.2 \mathrm{~cm}$. National Maritime Museum, Greenwich, BHC4237 (artwork in the public domain) [side-by-side viewer]

The children's portraits appear to be set in the hunting park of the Harington family seat of Coombe Abbey, in Warwickshire. Sir John and Prince Henry were friends, and Elizabeth lived under the guardianship of Lord John Harington until her marriage to Frederick V, Elector Palatine, in 1613, shortly after Henry's death (probably from typhoid), after which she departed to Heidelberg. Henry and Elizabeth perform idealized aspects of gendered participation in the courtly hunt. He is the martial nobleman, a leader among his peers, while her destiny is marital, 
as indicated by the couple seated in the bower in the background. ${ }^{21}$ Henry is shown sword in hand, at a critical moment in the process of the courtly hunt-the commencement of the ritual undoing, or flaying of the quarry; again, the privilege of the hunt's most senior member. His commanding pose situates him as a worthy heir to the throne, ready to assume the leadership of his armies and the governance of his kingdom.

But Anna's martial pose in Anne of Denmark cannot be straightforwardly situated within this binary gender patterning; her masculine excess points to the complexity of the portrait's address. Anna's pose is anticipated by those of her father and brother within their portraits woven into the series of genealogical tapestries known as the "king tapestries," elements of which survive in the Danish National Museum, Kronborg Palace, and Stockholm's Nationalmuseum. ${ }^{22}$ These were commissioned by Anna's father, Frederik II, in late 1581 from the Flemish emigré Hans Knieper, whose workshop had recently been established in Copenhagen. When hung in the Great Hall of the Danish castle of Kronborg, they covered the entire wall surface, measuring 560 square meters. The completed series illustrated a one-thousand-year-old genealogical line, portraying one hundred Danish rulers - one of whom, Margaret I, was female-on forty tapestries, supplemented by three hunting scenes. Completed in 1585, the series concluded with the one hundredth ruler, the reigning King Frederik II, who was portrayed on the last tapestry with his son, the Crown Prince Christian, later Christian IV, brother to Anna of Denmark (fig. 10). Frederik's great architectural projects - the castles of Kronborg, Frederiksborg, and Rosenborg-are arranged along the horizon, in defiance of their real topography, and court astronomer Tycho Brahe stands conversing in the background. The King wears armor, and his favorite hunting dog, Wilpret, waits by his feet. His reign represents martial success, scientific achievement, and cultural prowess.

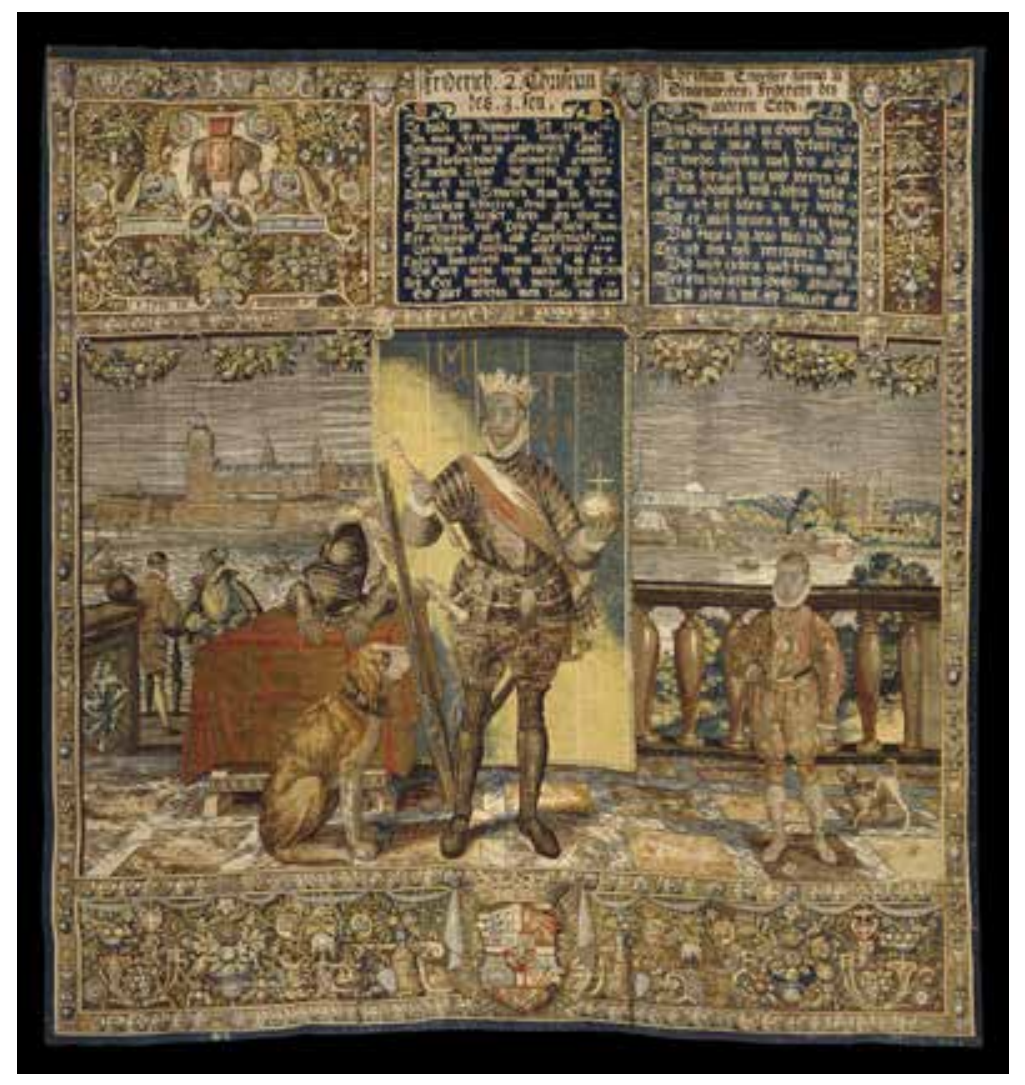

Fig. 10 Hans Knieper, Tapestry of Frederik II and Crown Prince Christian, 1581-85, wool and silk, approx. 394 x $367 \mathrm{~cm}$. National Museum of Denmark, Copenhagen; Kronborg Castle, Helsingør (artwork in the public domain) 
Each tapestry includes a small panel containing a moralizing verse that describes the ruler and his or her reign, along with its successes and failures, comprising an encyclopedia of wise, foolish, and at times even tyrannical rulership. ${ }^{23}$ The rhyming verses are mnemonic devices, enabling viewers to remember their lessons, suggesting that the tapestries were intended to deliver a sustained impact upon viewers.

A little later, Frederik added a throne baldachin canopy and backcloth to the commission for himself and his queen. Taken as war booty, it now forms part of the collection of the Nationalmuseum of Sweden in Stockholm. Elizabeth Cleland has noted, "This was an inspirational moment of proto-Baroque theatre on the part of Frederick and his advisers: in a room encircled by ... rulers represented in tapestry, the centrepiece would be the actual ruler himself, living, breathing, and framed against a tapestry surround." 24 This perceptive analysis highlights the way that this tapestry room functioned on multiple levels as historia, portraiture, and architecture, producing a heterotopic space presenting the reigning monarch as the culmination of the dynasty: genealogy perfected by ingenium (a person's extraordinary, innate talent, often thought to be gifted to them by heaven). ${ }^{25}$ Frederik embodies the triumph of the individual will and intelligence over destinyor perhaps, in this case, dynasty. His royal portrait is one of the first to present a king as a fully developed individual of his own creation, rather than a mere link in a dynastic sequence. Yet the king remains aware of his historicity within the chain of succession, as indicated by his inclusion of his young son and heir within his individual tapestry.

The king tapestries were famous throughout Europe, and no less so in England during Anna's tenure as consort. Their expository, instructive tone, coupled with the themes of dynasty and the chain of succession, also inflects her portrait by van Somer. Emulating her father, Anna (as indicated by her motto) deploys her own self-fashioning-defined as the art of (re)creating oneself in the image of one's best exemplars, using one's God-given reason-to augment her venerable genealogy. ${ }^{26}$ Aesthetically too, her portrait and the tapestry series exhibit commonalities. Like her children, and like the standing figures in the Danish genealogy tapestries, Anna is shown inhabiting an identifiable, exterior topographical space: the hunting park of Oatlands Palace. Anna is standing upright, with the palace visible in the distance, a composition recalling those of the individual tapestries. Anna's portrait refers to her Danish genealogy while anchoring it in a British context, while the Stuart succession is extended back through the Danish line.

Anna's portrait also anticipates Anthony van Dyck's portrait of Charles I of about 1635, now in the Louvre (fig. 11). This astonishing portrait shows the king, like Anna, standing beside his horse,

18 accompanied by his groomsman. Charles rests his fist upon his hip, his elbow jutting toward the viewer, his turned stance mirroring that of his mother. Despite his assertive pose, the overall mood is rather contemplative. Charles presents himself, perhaps contrary to our expectations, somewhat more as a thinker than a martial leader. Walter Liedtke notes that it is surprising that van Somer's Anne of Denmark and van Dyck's Charles I have never been considered to be pendants, as their dimensions are almost exactly the same. ${ }^{27}$ In what follows, I will argue that these similarities are not accidental. These two works are kin in terms of both blood and art, and they actively articulate their subjects as mother and son, teacher and pupil, the model and its perfection. 


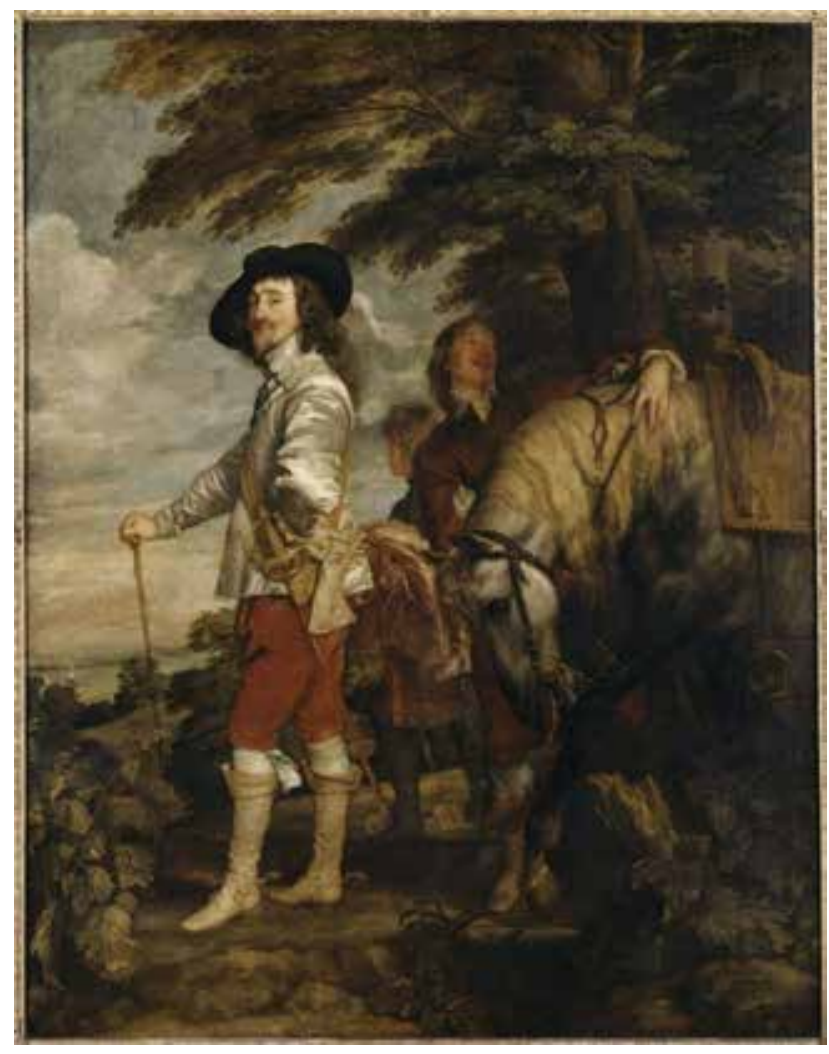

Fig. 11 Anthony van Dyck, Charles I, King of England (1600-1649), also known as Le Roi à la chasse, ca. 1635, oil on canvas, $266 \times 207 \mathrm{~cm}$. Musée du Louvre, Paris, INV. 1236. Photo (C) RMN-Grand Palais (musée du Louvre) / Christian Jean

Christopher Foley has observed that the development of the "dismounted equestrian portrait," as materialized successively in the hunting portraits of Henry, Anne, and Charles, narrates the transference of increasingly sophisticated Netherlandish skills to a Stuart visual context, established by the English painter Peake at the commencement of the dynasty's English reign..$^{28}$ This is a seductive but ultimately flawed teleological narrative of aesthetic development, which passes over the purposeful agency of the political image in its early modern context. Anna's portrait's address to her son, and Charles's portrait's response to it, position them within a dialogic, intergenerational cultural transfer, transacting ideas of inheritance, individuality, historicity, artistic originality, and elite self-fashioning. Her pose highlights her indispensable role in preserving the body politic for the Stuart succession; her elbow anticipates the authority of her son as King. As indicated by the presence of Minerva's bird, a symbol of wisdom, Anna may seek here to provide her son with a teachable model of masculine majesty to emulate. Charles's active reception and digestion of this lesson, his use of it as an inspiration for his own self-fashioning as king, is made manifest in his own portrait by van Dyck. The courtly hunt provides the arena, both real and represented, in which these transactions were made. As in art, so in life: the courtly hunt was a practice long developed across Asia and Europe for the preparation of princes for their future roles as kings.

\section{The Courtly Hunt as Princely Pedagogy}

Hunting, especially par force hunting, was a privilege restricted to the nobility. The exclusion of other ranks was legitimated by framing hunting as military training. The courtly hunt's ceremonial battles with the animal world were inherently representational: staged rehearsals for the military campaigns that noblemen were expected to lead as the warrior elite. To this extent, hunts were performances whose actors showed their readiness to defend their subjects. Hunts were also 
performative in that they constituted and perfected noble masculinity.

The courtly hunt played an important role in the education of princes, a role articulated within the interlocking framework of cynegetic and conduct literatures. The circulation of cynegetic manuals in manuscript, and later in print, which describe in detail the processes by which various animals should be hunted, was essential to the trans-aulic development of the ritualistic hunt across Western Europe. ${ }^{29}$ Late sixteenth- and early seventeenth-century translations of key works into English, and modernized editions of older English works, often feature passages comparing the nuances of British practice with that of its medieval forebears, European neighbors, or antique exemplars. $^{30}$

Cynegetic and conduct literatures describe the ideal behavior and attitude of the young nobleman toward his hunting practice and the nature of the courtly hunt's performative effects on noble masculinity. This tradition begins with Xenophon's ancient Cyropaedia. This Greek work originated the literary genre of princely pedagogy that became known as the "Mirror of Princes," of which perhaps Niccolò Machiavelli's The Prince (1532) and Baldassare Castiglione's The Book of the Courtier (1528) are the best-known examples. Within the Nordic region, the thirteenth-century Norwegian manuscript of the Konungs Skuggsjá, or King's Mirror, forms the earliest example of this genre. Within this tradition, Anna's dynastic portrait acts decisively as an exemplary mirror for her son.

This tradition continued in England with those writing under the reign of James VI and I; his extended address to his son Henry, Basilikon Doron (1599), constituted an exemplary pedagogical text that few seeking patronage could afford to ignore. ${ }^{31}$ However, I will focus here on Henry Peacham's The Compleat Gentleman (1622) and James Cleland's Hērō-paideia, or Institution of a Noble Young Man (1607), both of which draw on, cite, and respond to James's text. ${ }^{32}$ Peacham's career as a poet, emblem designer, and author is well documented; the lesser-known Cleland appears to have been a Scot, working as tutor to Sir John Harington, Prince Henry's companion. ${ }^{3}$

James deals briefly with the courtly hunt in the third book of the Basilikon Doron, within a longer section on physical exercise. He advises his son that hunting with running hounds is the "moste honorable and noblest sorte" of hunting. Cleland and Peacham deal with the sport and its effects more fully. Both writers concur that hunting trains the mind as well as the body. As Cleland here describes it:

there is noe exercise so proper unto you as Hunting, with running hounds, wherby your bodie is disposed to endure patiently, heat, raine, wind, cold, hunger, and thirst; your minde made voide of al idle and naughtie cogitations, as it appeareth by the chast Diana. Hunting formeth the Judgment, and furnisheth a thousand inventions unto the Imagination: it maketh a man couragious and valiant, in his enterprises. ... How am I able to reckon, the surprises, the strategems used for the obtaining of victorie, according to the beastes you doe hunt, which are all requisite $\&$ imploied without difference at the warrs, the hunting of men. ${ }^{34}$

The hunt prepares a man for far-reaching military leadership. Its physical rigors increase his tol- 
erance of discomfort and strengthen his self-control; they demand concentration, judgment; and imagination. Hunting is not solely a trial of physical strength but of a man's personal qualities. Henry Peacham writes:

Hunting, especially, which Xenophon commendeth to his Cyrus, calling it a gift of the Gods, bestowed first upon Chiron for his vprightnesse in doing Iustice, and by him taught vnto the old Heroes and Princes; by whose vertue and prowesse (as enabled by this exercise) their Countries were defended, their subjects and innocents preserved, Iustice maintained.

Hunting prepares leaders for the public responsibilities of the defense of the realm from external enemies and maintaining the rule of law within it; such training includes a moral dimension. The pleasure afforded by the hunt is such that it requires great fortitude to pursue it with moderation. Cleland writes, "Morouer hunting is so pleasant, that if reason were not obaied, manie could not returne frõ such an exercise more then Mithridates who remained seauen yeares in the forrest." 36 Cleland warns against the nobleman's surrender to the pleasures of hunting in the severest terms: "For if you neglect your necessarie affaies, you deserve to be punished with Lycaon, and Acteon, who were both hunted and killed by their owne dogges." 37

The specter of excess, of reason abandoned to passion, haunts hunting's status as the act most performative of exemplary, elite masculinity. Submission to passion undermines the ethical edifice that noble masculine privilege constructed for itself within the hunt's circumscribed processes. The strength to resist the hunt's private pleasures form a pillar of its purpose as a training ground to public duty. Temperance and moderation are the ethical imperatives that legitimize the political asymmetry inherent in early modern monarchy; self-control is the hallmark of the just governance of others. Peacham writes: "And albeit it is true as Galen saith, we are commonly beholden for the disposition of our minds, to the Temperature of our bodies, yet much lyeth in our power to keep that fount from empoisoning, by taking heed to ourselves; . . . to correct the malignitie of our Starres with a second birth." 38 These views were common across the Protestant northwestern periphery of Europe, dovetailing even with the responsibilities of Tycho Brahe as astronomer to Anna's father, Frederik II of Denmark, which included the casting of natal horoscopes. As John Robert Christianson has shown, Brahe's understanding of celestial influence did not rule out an orthodox Lutheran view on free will: "Men have something higher in themselves, which overcomes the heavenly and elemental influences," Brahe writes in the Astrologia of 1591. "And the human being conveyed by his reason and manifold thoughts, and alignments, is not so easily transformed and moved, as the unreasonable beasts. But a few men more or less so than the others." ${ }^{39}$

Such discourses privilege the cool head, the seat of reason, over the labile body natural, subject to the ebbs and flows of its passions. "Mind over matter" is a distinction of rank within the body analogous to the control of the sovereign over the state. As Jonathan Gil Harris has written: "The members of bodies natural and politic share a pathological predispensation to imbalance, discord and unruliness, the corrective to which is the beneficent, yet decidedly authoritarian, intervention of the soul and/or ruler." ${ }^{40}$ The hunt, therefore, offered a means of profoundly fleshly self-fashioning, constituting, to coin Peacham's phrase, a "second birth." 
The pedagogical theme extends to Anna's spirited little hunting dogs (see detail, fig. 12). ${ }^{41}$ Claude Anthenais, drawing on the French name for the greyhound-lévrier, or hare-courser-suggests in his analysis of the portrait that the Queen is hunting hares (as appears to have been her custom, as we have already seen). ${ }^{42}$ Following this, I suggest that Anna's dogs are young greyhounds that she is training in the field. Greyhounds began their training by hunting hares, as the hares' ingenuity (their doublings and crossings) taught young dogs perseverance. Although not specifically identified as Italian greyhounds in these sources, black-and-white hunting dogs appear in both French and English cynegetic literatures. George Gascoigne writes: "Now in our latter experience in this kingdome [England], we find the white Dog, and the white dog spotted with blacke, to bee ever the best hunters, especially at the Hare." 43 Jacques Espée de Selincourt, in Le Parfait Chasseur, writes: "Of the three main kinds of dogs the English have, the largest and most beautiful are said to be of the royal race, and are white marked with black." ${ }^{44}$ For those viewers familiar with these literatures, the portrayed scene could function as a witty allegory. Just as Anna teaches the young dogs of the English royal race to navigate the hunting field, so too she performs exemplary majesty for the young Charles, then in training to be the future king of the larger field of Great Britain.

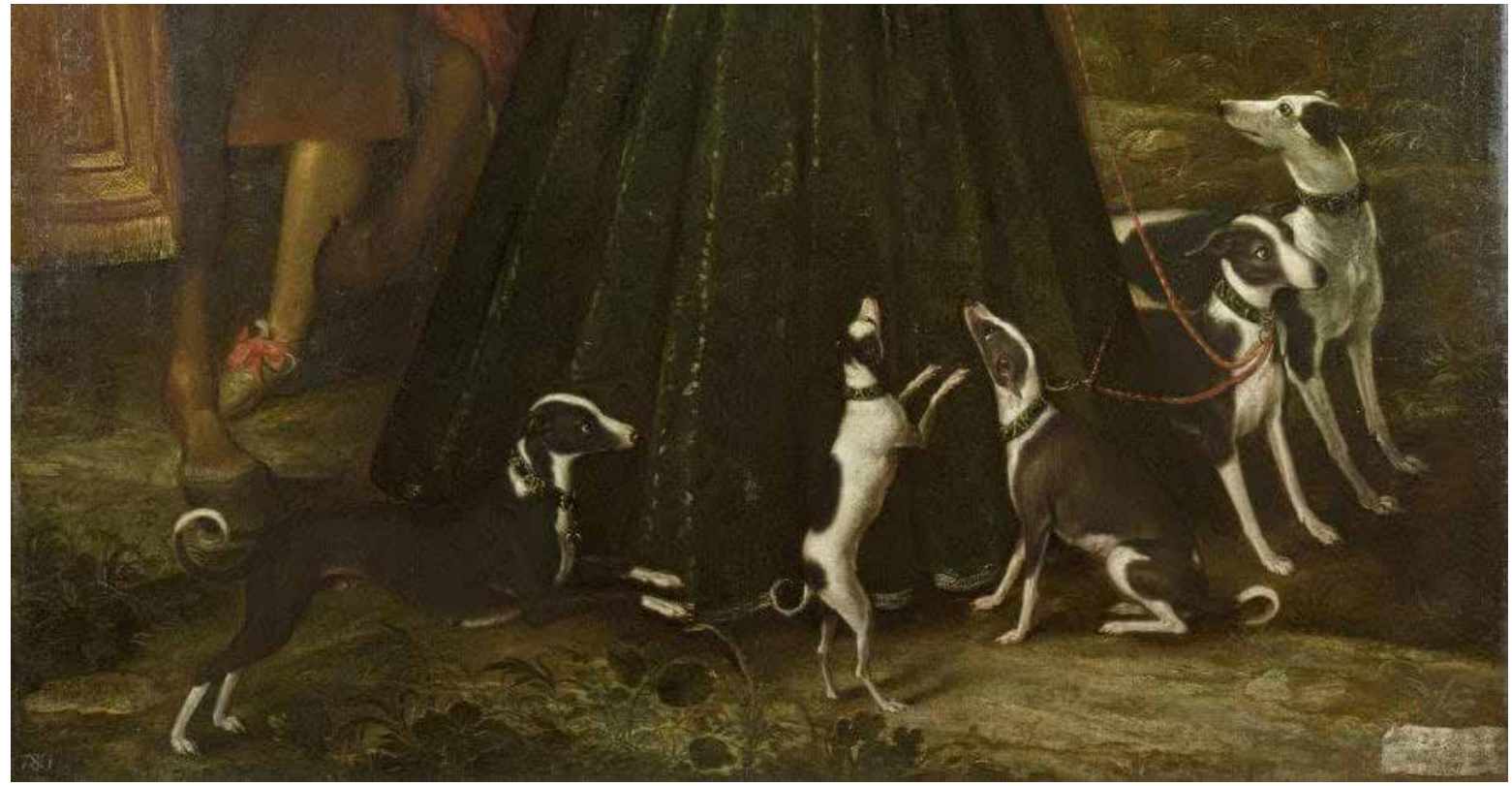

Fig. 12 Paul van Somer, Anne of Denmark (fig. 1), detail (@ Her Majesty Queen Elizabeth II 2020 London, RCIN 405887) [side-by-side viewer]

Within this scenario, the privileging of reason over strength as the foundation of rulership persists. As the wiliest of all prey animals, the hare was especially a test of a hunter's and her dogs' intelligence and strategy. In the sole textual reference to women's (and indeed scholars') hunting practice that I am aware of, in the Boke of the Governor (1537), Thomas Elyot writes: "Huntyng of the hare with grehoundes is a right good solace for men that be studiouse, or them to whom nature hath not given personage or courage apt for the warres. And also for gentilwomen which fear neither sonne nor wynde for appairing their beauty." ${ }^{35}$ Hares also possessed other cultural valencies. In his edition of Juliana Berger's The Book of St. Albans, Gervase Markham writes: “The Hare is the King of al the beasts of Venerie, and in hunting maketh best sport, breedeth the most delight of any other, and is a beast most strange by nature, for he often changeth his kinde, and is 
both male and female." ${ }^{46}$

This theory of the hare's hermaphroditism was thoroughly debunked by Edward Topsell in his 1607 translation of Conrad Gesner's magisterial zoological tract Historioe Animalium; nevertheless, the myths of the bestiaries retained their cultural currency well into the seventeenth century. ${ }^{47}$ Animals' special qualities were preserved in vernacular oral culture, and their stories were used to inspire young scholars to read their books, as Cleland recommends. ${ }^{48}$ John Robert Christianson has shown that Anna hunted hares with her sister Elizabeth; her father, Frederik II; and her mother, Sophia, as a young woman in Denmark. ${ }^{49}$ Hares may have had some special significance at the Danish court; Hans Knieper's Kronborg workshop produced a series of tapestries portraying them, which are now lost. ${ }^{50}$ Within the Danish context, the hare may have been identified with Loki, who as the clever, shape-shifting, gender-fluid trickster of Norse mythology was perhaps the ultimate master of self-fashioning.

\section{Genealogy and Ingenium}

Hans Belting has argued that a shift in the concept of the portrait by the humanist artists of the Northern Renaissance during the sixteenth century revisioned the "Self" so that it was no longer understood as something fully contiguous with the body, but separate from it. ${ }^{51}$ Within the portrait, the physiognomic view of the body was gradually superseded by a new visual-textual rhetoric of the Self. While this new rhetoric served intellectual humanists and other members of the non-noble classes by articulating their claims to social status-and to representation-it was also co-opted by those with venerable dynastic genealogies, such as Frederick the Wise, as Belting shows. ${ }^{52}$ Within the courtly class, genealogy became paired with ingenium. A body's fleshly, inherited nobility was crowned with the personal distinction conferred by the innate qualities of the individual: their God-given reasoning and creative powers. So James Cleland writes of James VI and I: "I maie affirme there is one like a Quintessence, above the foure elements, which containeth such wits, as appeare not to bee taught or informed by men, but infused by God; they are able in the twinkling of an eie, at the first motion to conceive, invent and retaine al things most accurately. Of such wits I have never seene, read or heard of one comparable to the King's Majesty." ${ }^{33}$

Of course, venerable genealogy retained its importance for the self-imaging of elites, since the association between noble blood and superior virtue only served to further legitimize their privilege. As James writes in Basilicon Doron, referencing the theology of traductionism (the theory that original sin is transmitted from parents to children): "For though, anima non venit extraduce [the soul does not come by traduction], but is immediately created by God, and infused from above: yet it is most certaine that virtue or vice will oftentimes with the heritage bee transferred from the parentes to the posteritie and run on a blood (as the Proverbe is). \&c." ${ }^{54}$ While a virtuous genealogy retained its importance to royal identity within hereditary monarchy, this inheritance was balanced and enhanced by the ruler's individual, even divine attributes.

Similarly, for artists of all disciplines, ingenium was conceived as a God-given talent for originality, equipping an individual to create something brand new from the models available to him or her, rather than merely repeating them. The proper assimilation and phenomenological digestion of a rich array of precedents stored in the memory nourished the inborn genius, enabling it to surpass and perfect its models. The intertwining theories of imitation and innutrition taught that 
the assimilating and digesting of many precedent perfections, like the honeybee visiting many flowers, would assist student practitioners of painting, poetry, rhetoric, or indeed, rulership, to construct their own new and original styles. Peacham couches his advice to young nobles on developing their style by speaking in just these terms, while drawing on a series of examples of artisanal expertise:

For as the young Virgin to make her fairest Garlands, gathereth not altogether one kinde of Flower; and the cunning Painter, to make a delicate beautie, is forced to mixe his Complexion, and compound it of many colours; the Arras-worker, to please the eyes of Princes, to be acquainted with many Hiftories: so are you to gather this Honey of eloquence, A gift of heaven, out of many fields; making it your owne by diligence in collection, care in expreffion, and skill in digeftion. ${ }^{5}$

In the wake of Anna's death, her portrait offered her son an image to instruct and nurture him. Selecting a diet within the humoral regimes that structured the early modern body was an act of self-fashioning in its most literal sense, affecting the quality and comfort of body and mind. So, too, selecting a diet of images was informed by the potential effects on the physical and mental interiority of the viewer. Consumption of food, drink, and art were all part of a "highly complex network of influences on character and health," and all required the discipline of temperance. ${ }^{56}$ As Denis Ribouillault has noted, a taste for painting was not necessarily an untrammeled virtue. ${ }^{57}$ Indiscriminate "binging" on images without carefully selecting and properly digesting them could lead to dubious encounters with the early modern medical profession. This is demonstrated in a print in which patients of Dr. Panurgus are purged of a surfeit of images by variously scatological means (fig. 13). A well-to-do courtier's head is steamed in an oven to evaporate the frivolous images that have congested in his brain. A rather less well-to-do client is purged of his poorly digested images on a close stool, or commode. The accompanying text states that "millions" have resorted to this grave doctor, suggesting that the fashionable consumption of high art could lead as often to widespread dangerous delusions as to virtuous erudition. This may seem rather prescient in light of Charles's later career as perhaps the most discerning collector and commissioner of art the British succession has ever produced, and also as leader of the defeated Royalist armies.

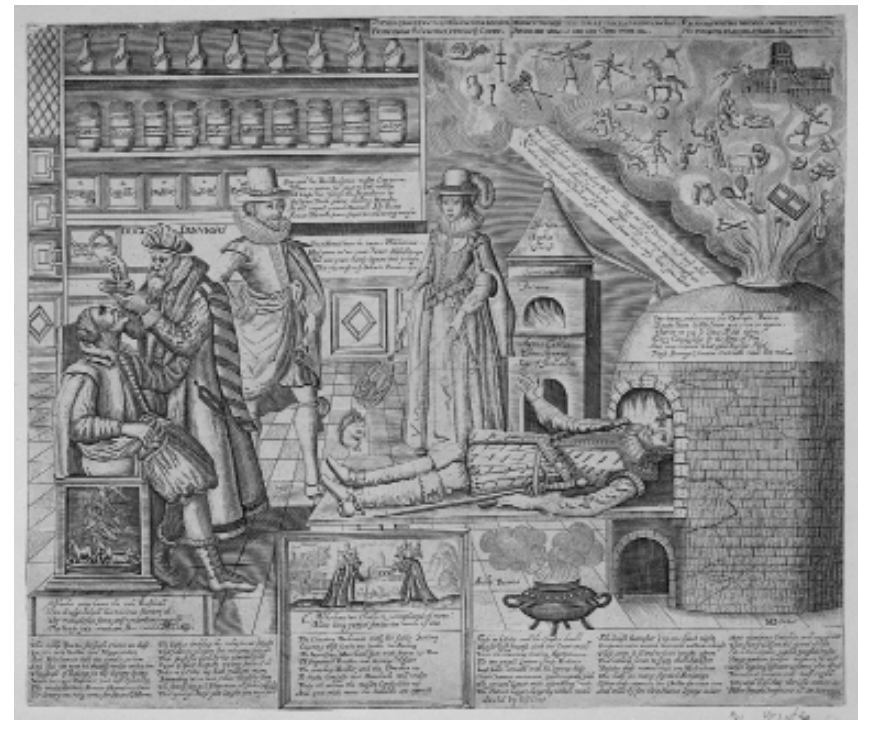

Fig. 13 Attributed to Michael Droeshout (design), John Overton and Peter Stent (publishers), "Doctor Panurgus" Curing the Folly of His Patients by Purgative Medicines and Chemical Cures, 1600s, engraving, $34.4 \times 41.1 \mathrm{~cm}$ (sheet). Wellcome Collection: Attribution 4.0 International (CC BY 4.0) 
Such graphic pastiches are dependent on the reception theory of the period, which argues for the transformative agency of the exemplary portrait. Richard Haydocke's translation of Gian Paolo Lomazzo's Trattato dellarte della Pittura, Scoltura et Architettura (1584) maintained that painting had the power to move the beholder literally, and he conceptualized the body as a medium for the imprinting and storing of images, as Hans Belting has more recently argued. ${ }^{58}$ Haydocke writes: "So a picture artificially expressing the true naturall motions, will (surely) procure laughter when it laugheth, pensiuenesse when it is grieued \&c." ${ }^{59}$ He goes on to explain that a beholder will feel his appetite moved when he sees delicacies being eaten or will experience fury at a heated battle scene. A beholder before a portrait of exemplary majesty would, theoretically, experience his reception of an image physically and feel the literal impression being made upon him by the scene before his eyes. As Thijs Weststeijn has written, "Taken to the extreme, this means the beholder is supposed to 'become' the work, as ultimately he takes on the work's qualities." ${ }^{\prime 0}$ The image fashions the viewer.

Ingenium was thus linked dialogically with genealogy in all kinds of creative practice. As Aileen A. Feng notes in relation to poetry, "the relationship between the source texts and the new one should be modeled on that between a father and his son: a subtle resemblance, but not an exact replica." ${ }^{61}$ A well-stocked visual memory is of central importance to both making and experiencing art, since much of its pleasure is in the recognition of the visual allusions that a work makes to its precedents. As Elizabeth Cropper has shown in relation to the Caracci family of painters:

Artists in the humanist tradition of painting ... were just as concerned with inventing, disposing and ornamenting themes through allusive cross-references as they were with the representation of natural effects or the invention of new subject matter altogether. ... Works of art relied as much, if not more, upon familial relationships with other works of art as they did on comparisons with living nature. ${ }^{62}$

Within this allusive culture, Anna's portrait exceeds its place as a link in an aesthetic genealogical chain. According to this reading, Anna is no longer the passive subject of a portrait whose story narrates a prologue in an artistic succession, from Peake to van Somer to van Dyck, to which she is only somewhat incidental. Anna, by means of her portrait, intervenes and demonstrates her contributive agency within the historical process of the princely succession. As sitter, mother and queen, Anna's portrait anticipates, even interpellates, the portrait of her son.

\section{Concluding Thoughts}

By reading into Anna's pictorial genealogy, the rich and complex early modern cultures of the hunt, and contemporary theories of art making and reception, we are able to recognize a reciprocal dialogic engagement between van Somer's Anne of Denmark and van Dyck's Charles I. Van Dyck's Charles may now be regarded as a material reception of van Somer's Anne and as evidence of how Charles's kingly self-fashioning was constructed in light of her example. This is not to minimize the contribution of either van Somer or van Dyck in taking forward the theme of the dismounted equestrian ruler portrait in new and innovative directions. Both artists' authorship is clearly legible in the portraits they painted for their royal sitters. It would be unwise to assume that these artists, having trained in the richly creative and innovative tradition of the Low Countries, had no input into the composition of the works of art they painted. The intent of this article, 
rather, has been to reintegrate the queen and her son, the king, as thinking agents acting within this process and upon its artistic outcomes. Genealogy and ingenium have often been mapped against the royal sitter and the commissioned artist, respectively. This essay argues that both the possession of heritage and the powerful ability to fashion and create are qualities brought to bear by artist and patron in the production of these original portraits.

The queen, whose body has physically regenerated the dynasty and whose portrait provides the next generation with its perfect exemplar, is doubly figured as the ultimate reproductive medium. Her portrait is much more than a mere screen for the projection of monarchical and dynastic aura. The portrait's witty composition should remind us that both the sitters and viewers of Renaissance court portraits were often more adept and erudite than historians have recognized, and that their splendid portraits contain greater political agency and self-awareness than is sometimes assumed.

\section{Acknowledgements}

I would like to especially thank Peter Funnell, formerly Head of Research at the National Portrait Gallery, London, and Mette Skougaard and Thomas Lyngby of the Museum of National History at Frederiksborg Castle, Denmark, and to gratefully acknowledge the financial support of the Carlsberg Foundation. Elements of this work were developed via conference papers given at events organized by the Society for Court Studies, by Julie Farguson of Wolfson College, Oxford, at KHI Munich and the University of Leiden. I thank the respondents at these events for their thoughtful questions. I also thank Joanna Marschner and Anne Byrne for reading and commenting on early versions of this essay and the JHNA reviewers for their helpful feedback.

Sara Ayres is currently a visiting fellow at the Centre for Privacy Studies, University of Copenhagen, supported by the Nordea Foundation. Research for this article was undertaken during her tenure as the Queen Margarethe II Distinguished Postdoctoral Fellow, funded by the Carlsberg Foundation, at the National Portrait Gallery, London, from 2016 to 2018.

ayressara@hotmail.com

\section{List of Illustrations}

Fig. 1 Paul van Somer, Anne of Denmark, signed and dated 1617, oil on canvas, 265.5 x $209.0 \mathrm{~cm}$. Royal Collection Trust / (c Her Majesty Queen Elizabeth II 2020 London, RCIN 405887

Fig. 2 Hans van der Biest after a design by Pieter de Witte, April tapestry from the Months of the Year series, 1612-14, silk, wool, and metal thread, 407-10 x 523-28 cm. Residenz, Munich, Inv.Nr. BSV.WA 38. (C) Bayerische Schlösserverwaltung Maria Scherf/Andrea Gruber, München 
Fig. 3 Hans van der Biest after a design by Pieter de Witte, July tapestry from the Months of the Year series, 1612-14, silk, wool, and metal thread, 408-9 x 525-30 cm. Residenz, Munich, Inv.-Nr. BSV.WA0041. (C) Bayerische Schlösserverwaltung Maria Scherf/Andrea Gruber, München

Fig. 4 Hans van der Biest after a design by Pieter de Witte, November tapestry from the Months of the Year series, 1612-14, silk, wool and metal thread, 409 x 524-28 cm. Residenz, Munich, Inv.Nr. BSV.WA 45. (C) Bayerische Schlösserverwaltung Maria Scherf/Andrea Gruber, München

Fig. 5 Peter Paul Rubens, Wolf and Fox Hunt, ca. 1616, oil on canvas, 245.4 x $376.2 \mathrm{~cm}$, Metropolitan Museum of Art, New York, John Stewart Kennedy Fund, 1910 (10.73) Image courtesy the Metropolitan Museum of Art (artwork in the public domain)

Fig. 6 Attributed to Karel van Mander (design), François Spierinx (maker), Cephalus and Procris tapestry from the Histories of Diana series (ca. 1593-1610), wool and silk on a woolen weft, 354 (left)-351 (right) x 546 (upper)-542 (lower) cm. Rijksmuseum, Amsterdam, BK-1954-69-B (artwork in the public domain)

Fig. 7 Attributed to Karel van Mander (design), François Spierinx (maker), Meleager and Atalanta tapestry from the Histories of Diana series, ca. 1593-1600, wool and silk on a woolen weft, 351 (left)-347 (right) x 469 (upper)-468 (lower) cm. Rijksmuseum, Amsterdam, BK-2006-77 (artwork in the public domain)

Fig. 8 Robert Peake the Elder, Henry Frederick Prince of Wales, with Sir John Harington in the Hunting Field, 1603, oil on canvas, 201.9 x $147.3 \mathrm{~cm}$, Metropolitan Museum of Art, New York, Purchase, Joseph Pulitzer Bequest, 1944 (44.27) Image courtesy the Metropolitan Museum of Art

Fig. 9 Robert Peake the Elder, Princess Elizabeth, 1603, oil on canvas, $135.9 \mathrm{~cm} \mathrm{x} 95.2 \mathrm{~cm}$. National Maritime Museum, Greenwich, BHC4237 (artwork in the public domain)

Fig. 10 Hans Knieper, Tapestry of Frederik II and Crown Prince Christian, 1581-85, wool and silk, approx. 394 x 367 cm. National Museum of Denmark, Copenhagen; Kronborg Castle, Helsingør (artwork in the public domain)

Fig. 11 Anthony van Dyck, Charles I, King of England (1600-1649), also known as Le Roi à la chasse, ca. 1635, oil on canvas, 266 x 207 cm. Musée du Louvre, Paris, INV. 1236. Photo (C) RMN-Grand Palais (musée du Louvre) / Christian Jean

Fig. 12 Paul van Somer, Anne of Denmark (fig. 1), detail () Her Majesty Queen Elizabeth II 2020 London, RCIN 405887)

Fig. 13 Attributed to Michael Droeshout (design), John Overton and Peter Stent (publishers), "Doctor Panurgus" Curing the Folly of His Patients by Purgative Medicines and Chemical Cures, 1600s, engraving, $34.4 \times 41.1 \mathrm{~cm}$ (sheet). Wellcome Collection: Attribution 4.0 International (CC BY 4.0) 


\section{Bibliography}

\section{Manuscripts and Archives}

Book of Hours, ca. 1500, known as the "London Rothschild Hours" or "Hours of Joanna of Castile." British Library, Add MS 35313 f.158v.

Diary, c. 1672-1683, miscatalogued as Journal of the Travels of the Crown Prince of Denmark, afterwards Christian V. British Library manuscripts Add MS 12487 and Add MS 12488.

State Papers Online: MS Secretaries of State: State Papers Domestic, James I, 1603-1640. The National Archives of the UK.

\section{Published Literature}

Adams, Simon. “'The Queenes Majestie ... is now become a great huntress': Elizabeth I and the Chase." The Court Historian 18, no. 2 (2013): 143-64. HTTPS://DOI.ORG/10.1179/ COU.2013.18.2.002.

Allsen, Thomas. The Royal Hunt in Eurasian History. Philadelphia: University of Pennsylvania Press, 2006.

Almond, Richard. Daughters of Artemis: The Huntress in the Middle Ages and Renaissance. Cambridge: Brewer, 2009.

Ayres, Sara, ed. “The Northern Line: Representing Danish Consorts in Scotland, England and Great Britain." Special issue, The Court Historian: The International Journal of Court Studies 24, no. 2 (August 2019).

Belting, Hans. An Anthropology of Images: Picture, Medium, Body. Princeton: Princeton University Press, 2011. Calendar of the Manuscripts of the most Hon the Marquis of Salisbury, vol. 17, ed. M. S. Guiseppi. London: HMSO, 1938.

Campbell, Thomas P. “Continuity and Change in Tapestry Use and Design, 1680-1720.” In Campbell, ed., Tapestry in the Baroque, 491-507.

- - - ed. Tapestry in the Baroque: Threads of Splendour, New Haven and London: Yale University Press, 2007.

Christianson, John Robert. “The Hunt of King Frederik II of Denmark: Structures and Rituals," The Court Historian 18, no. 2 (2013): 165-87. HTTPS://DOI.ORG/10.1179/COU.2013.18.2.003.

Christianson, John Robert and Tycho Brahe. "Tycho Brahe's Cosmology from the Astrologia of 1591." Isis 59, no. 3 (1968): 312-18. Cleland, Elizabeth. "1. Throne Baldachin." In Campbell, ed., Tapestry in the Baroque, 33. HTTPS://DOI.ORG/10.1086/350400. 
Cleland, James. Hērō-paideia, or the Institution of a Young Noble Man. London: Joseph Barnes, 1622.

Cropper, Elizabeth. The Domenichino Affair: Novelty, Imitation, and Theft in Seventeenth-Century Rome. New Haven: Yale University Press, 2005.

d'Anthenaise, Claude. Portraits en Costume de Chasse. Paris: Nicholas Chaudun, 2010. Digby, George Wingfield, assisted by Wendy Hefford. The Devonshire Hunting Tapestries. London: Victoria and Albert Museum, 1971.

Du Bec, Jean. Discours de l’Antagonie du Chien et du Lièvre. Paris: Librairie des Bibliophiles, 1880.

Duerloo, Luc. "The Hunt in the Performance of Archducal Rule: Endurance and Revival in the Habsburg Netherlands in the Early Seventeenth Century." Renaissance Quarterly 69 (2016): 116-54. HTTPS://DOI.ORG/10.1086/686328.

Dunn-Hensley, Susan. Anna of Denmark and Henrietta Maria: Virgins, Witches and Catholic Queens. Basingstoke, Hampshire: Palgrave Macmillan, 2017.

Elyot, Thomas. The Boke Named the Gouernour, Deuysed by Syr Thomas Elyot, Knight. London: Tho. Bertheleti, 1537.

Espée de Selincourt, Jacques. Le Parfait Chasseur. Paris: Gabriel Quinet, 1683.

Feng, Aileen A. Writing Beloveds: Humanist Petrarchism and the Politics of Gender. Toronto: Toronto University Press, 2017.

Field, Jemma. "Anna of Denmark and the Politics of Religious Identity in Jacobean Scotland and England, c. 1592-1619.” Northern Studies 50 (2019): 87-113.

- - - "A 'Cipher of A and C Set on the One Syde with Diamonds': Anna of Denmark's Jewellery and the Politics of Dynastic Display." In Sartorial Politics in Early Modern Europe: Fashioning Women, edited by Erin Griffey, 139-160. Amsterdam: Amsterdam University Press, 2019. HTTPS://DOI.ORG/10.2307/J.CTV10KMG51.10.

- - - "Dressing a Queen: The Wardrobe of Anna of Denmark at the Scottish Court of King James VI, 1590-1603." The Court Historian: The International Journal of Court Studies 24, no. 2 (August 2019): 152-67. HTTPS://DOI.ORG/10.1080/14629712.2019.1626120.

- - - "Anna of Denmark: A Late Portrait by Paul van Somer." The British Art Journal 18, no. 2 (2017): 50-56.

_-_. "The Wardrobe Goods of Anna of Denmark." Costume 51, no. 1 (2017): 3-27. HTTPS:// DOI.ORG/10.3366/COST.2017.0003. 
Fietze, Katharina. Im Gefolge Dianas: Frauen und Höfische Jagd im Mittelalter (1200-1500). Cologne: Böhlau, 2005.

Fiorato, Sidia. "Anna of Denmark and the Performance of the Queen Consort's Sovereignty." In Performing the Renaissance Body: Essays on Drama, Law and Representation, edited by Sidia Fiorato and John Drakakis, 247-72. Berlin: De Gruyter, 2016.

Foley, Christopher. "Somer [Someren], Paul [Pauwels] van." Grove Art Online, last updated 2003. HTTPS://DOI.ORG/10.1093/GAO/9781884446054.ARTICLE.T079700.

ffoliot, Sheila. "Catherine de' Medici as Artemisia: Figuring the Powerful Widow." In Rewriting the Renaissance: The Discourses of Sexual Difference in Early Modern Europe, edited by Margaret W Ferguson, Maureen Quilligan and Nancy J. Vickers, 227-41. Chicago and London: University of Chicago Press, 1986.

Franke, Birgit. "Jagd und landesherrliche Domäne: Bilder höfischer Repräsentation in Spätmittelalter und Früher Neuzeit." In Martini, ed., Die Jagd der Eliten, 189-218.

Francken, Johan. Chronica; Das ist: Beschreibung aller Könige in Dennemarcken / von dem Ersten Könige DAN: (welcher zur zeit des Königs Davidis regieret) biß auffChristianum den Vierdten dieses Namens ißt Regierenden und an der Zahl der hunderste. Magdeburg: n.p., 1597.

Gil Harris, Jonathan. Foreign Bodies and the Body Politic: Discourses of Social Pathology in Early Modern England. Cambridge: Cambridge University Press, 2006.

Greenblatt, Stephen. Renaissance Self-Fashioning: From More to Shakespeare. Chicago: University of Chicago Press, 2005. Originally published 1980.

Haag, Sabine, Dagmar Eichberger, and Annemarie Jordan Geschwend, eds., Frauen, Kunst und Macht: Drei Frauen aus dem Haus Habsburg. Innsbruck: Schloss Ambras, 2018.

Haelwegh, Albert. Regum Daniæ Icones. Hafniæ: Georg Holst, 1648.

Hamrick, Stephen. "Set in portraiture': George Gascoigne, Queen Elizabeth, and Adapting the Royal Image." Early Modern Literary Studies 11, no. 1 (May 2005): 1-30. HTTP://PURL.OCLC. ORG/EMLS/11-1/HAMRGASC.HTM.

Hartkamp-Jonxis, Ebeltje. Weaving Myths: Ovid's Metamorphoses and the Diana Tapestries in the Rijksmuseum. Amsterdam: Waanders, 2009.

Hearn, Karen. "Peake, Robert (c. 1551-1619), ortrait and decorative painter." Oxford Dictionary of National Biography. Last updated September 23, 2004. HTTPS://DOI.ORG/10.1093/REF:OD$\mathrm{NB} / 21685$. 
- - - "Somer, Paul [Pauwels] van [Paul Vansommer] (1577/8-1621/2), portrait painter." Oxford Dictionary of National Biography. Last updated September 23, 2004. HTTPS://DOI.ORG/10.1093/ REF:ODNB/28107.

-_-. "139. Anne of Denmark." In Dynasties: Painting in Tudor and Jacobean England 15301630, edited by Karen Hearn, 206-7. London: Tate Gallery, 1995.

Hitchmough, Wendy. "Setting' the Stuart Court: Placing Portraits in the 'Performance' of Anglo Spanish Negotiations." Journal of the History of Collections (February 2019): 1-20. HTTPS://DOI. ORG/10.1093/JHC/FHZ004.

- - - "Queenship and the Currency of Arts Patronage as Propaganda at the Early Stuart Court." In Royal Women and Dynastic Loyalty. Queenship and Power, edited by Caroline Dunn and Elizabeth Carney, 139-149. HTTPS://DOI.ORG/10.1007/978-3-319-75877-0_10.

Basingstoke, Hampshire: Palgrave Macmillan, 2018.

Horden, John. "Peacham, Henry (b. 1578, d. in or after 1644), writer and illustrator." Oxford Dictionary of National Biography. Last updated September 23, 2004. HTTPS://DOI.ORG/10.1093/ REF:ODNB/21667.

James VI and I. "Basilicon Doron." In King James VI and I: Political Writings, edited by Johan P Somerville, 1-61. Cambridge: Cambridge University Press, 1994. HTTPS://DOI.ORG/10.1017/ CBO9780511809743.006.

Koslow, Susan. "Law and Order in Rubens's Wolf and Fox Hunt." The Art Bulletin 78, no. 4, (1996): 680-706. HTTPS://DOI.ORG/10.2307/3046215.

Liedtke, Walter. The Royal Horse and Rider. New York: Abaris, 1989.

Lomazzo, Gian Paolo. A Tracte Containing the Artes of Curious Paintinge, Caruinge \& Buildinge. Translated by Richard Haydocke. Oxford: n.p., 1598.

Lund, E. F. S., and C. Chr. Andersen. Dansk Malede Portretter, vol. 2.2. Copenhagen: Gyldendal, 1897.

MacLeod, Catharine. "Facing Europe: the Portraiture of Anne of Denmark (1579-1619)." In Telling Objects: Contextualizing the Role of the Consort in Early Modern Europe, edited by Jill Bepler and Svante Norrhem, 67-86. Wiesbaden: Harrassowitz, 2018.

MacLeod, Catharine, Malcolm Smuts, and Timothy Wilks, eds., The Lost Prince: The Life \& Death of Henry Stuart. London: National Portrait Gallery, 2012.

Markham, Gervase. The Gentlemans Academie OR The Booke of S Albans: by GM. London: n.p., 1595. 
Marr, Alexander, "Pregnant Wit: ingegno in Renaissance England," British Art Studies 1 (November 2015). HTTPS://DOI.ORG/10.17658/ISSN.2058-5462/ISSUE-01/AMARR.

Martini, Wolfram, ed. Die Jagd der Eliten in den Erinnerungskulturen von der Antike bis in die frühe Neuzeit. Göttingen: Vandenhoeck und Ruprecht, 2000.

Meikle, Maureen. "Once a Dane, Always a Dane? Queen Anna of Denmark's Foreign Relations and Intercessions as a Queen Consort of Scotland and England, 1588-1619." The Court Historian: The International Journal of Court Studies 24, no. 2 (August 2019): 168-80. HTTPS://DOI.ORG/1 $0.1080 / 14629712.2019 .1626121$.

Millar, Oliver, ed. Abraham Van der Doort's Catalogue of the Collections of Charles I. London: Walpole Society, 1960.

-- - The Tudor, Stuart and Early Georgian Pictures in the Collection of Her Majesty the Queen. London: Phaidon, 1963.

_-_. "A Little Known Portrait by Paul Van Somer." The Burlington Magazine 92, no. 571 (1950): $294-96$.

Murray, Catriona. Imaging Stuart Family Politics: Dynastic Crisis and Continuity. London: Routledge, 2017.

Peacham, Henry. The Compleat Gentleman, Fashioning Him Absolute in the Most Necessary \& Commendable Qualities Concerning Minde or Bodie that May Be Required in a Noble Gentleman. London: n.p., 1622.

Pearce, Michael. "Anna of Denmark: Fashioning a Danish Court in Scotland." The Court Historian: The International Journal of Court Studies 24, no. 2 (August 2019): 138-51. HTTPS://DOI.OR G/10.1080/14629712.2019.1626110.

Pollnitz, Aysha. Princely Education in Early Modern Britain. Cambridge: Cambridge University Press, 2015.

Reindel, Ulrik. "The King Tapestries at Kronborg Castle: A 'Mirror for Princes' for a Protestant Prince." In Portrait et Tapisserie/Portrait and Tapestry, edited by Philippe Bordes and Pascal-Francois Bertrand, 71-87. Turnhout: Brepols, 2015.

Ribouillault, Denis. "Regurgitating Nature: On a Celebrated Anecdote by Karel van Mander about Pieter Bruegel the Elder." Journal of Historians of Netherlandish Art 8, no. 1 (Winter 2016). HTTPS://DOI.ORG/10.5092/JHNA.2016.8.1.4.

Rooney, Anne, ed. The Tretysse off Huntyng. Brussels: Omirel, 1987. 
Rösener, Werner. Die Geschichte der Jagd. Dusseldorf and Zurich: Artemis and Winkler, 2004.

Schlegel, Johann Friedrich, ed. Samlung zur Dänische Geschichte 3, no. 2. Copenhagen: Sander und Schröder, 1776.

Schoenfeldt, Michael. "Fables of the Belly in Early Modern England." In The Body in Parts: Fantasies of Corporeality in Early Modern England, edited by David Hillman and Carla Mazzio, 243-62. New York and London: Routledge, 1997. HTTPS://DOI.ORG/10.4324/9780203379554.

Selzer, Stephan. "Jagdszenen aus Sachsen: Die Jagd als Höfische Fest auf Einem Tafelgemälde vom Ernestinischem Hof (1540).” In Mitteilungen der Residenzen-Kommission der Akademie der Wissenschaften zu Göttingen, Sonderheft 6, Höfische Feste im Spätmittelalter, edited by Gerhard Fouquet, Harm von Seggern, and Gabriel Zeilinger, 73-90. Kiel: Akademie Der Wissenschaften Zu Göttingen, 2003.

Shackelford, Jole. A Philosophical Path for Paracelsian Medicine: The Ideas, Intellectual Context, and Influence of Petrus Severinus (1540/2-1602). Copenhagen: Museum Tusculanum Press, 2004.

- - - "Providence, Power and Cosmic Causality in Early Modern Astronomy: The Case of Tycho Brahe and Petrus Severinus." In Tycho Brahe and Prague: Crossroads of European Science, edited by John R[obert]. Christianson, Alena Hadravová, Petr Hadrava, and Martin Šolc, 46-69. Frankfurt: Deutsch, 2002.

Spicer, Joneath. “The Renaissance Elbow." In A Cultural History of Gesture, edited by Jan Bremmer and Herman Roodenburg, 84-128. Cambridge: Polity, 1991.

Tipping, H. Avray. English Homes Period V, vol. 1. London: Country Life, 1921. Topsell, Edward. The Historie of Foure-footed Beastes ... Collected out of All the Volumes of C. Gesner, and All Other Writers to this Present Day. London: n.p., 1607.

Town, Edward. “A Biographical Dictionary of London Painters, 1547-1625." The Volume of the Walpole Society 76 (2014): 1-235.

Turbeville, George [and George Gascoigne]. The Noble Arte of Venerie or Hunting. London: n.p., 1575. de Villermont, Countess Marie Hennequin. L'Infante Isabelle, Gouvernante des Pays-Bas. Paris: n.p., 1912.

Volk-Knüttel, Brigitte. Peter Candid (um 1548-1628): Gemälde, Zeichnungen, Druckgraphik. Berlin: Deutscher Verlag für Kunstwissenschaft, 2010. - - - Wandteppiche für den Münchener Hof, nach Entwürfen von Peter Candid. Munich: Deutscher Kunstverlag, 1976.

Warren, Jeremy. The Wallace Collection Catalogue of Italian Sculpture, vol. 1. London: Wallace Collection, 2016.

Weststeijn, Thijs. The Visible World: Samuel van Hoogstraten's Art Theory and the Legitimation of 
Painting in the Dutch Golden Age. Amsterdam: Amsterdam University Press, 2008. HTTPS://DOI. ORG/10.5117/9789089640277.

Whitelock, Anna. "Reconsidering the Political Role of Anna of Denmark." In Queenship and Counsel in Early Modern Europe, edited by Helen Matheson-Pollock, Joanne Paul and Catherine Fletcher, 237-58. HTTPS://DOI.ORG/10.1007/978-3-319-76974-5_11.

Basingstoke, Hampshire: Palgrave Macmillan, 2018. Woldbye, Vibeke. European Tapestries, 15th-20th Century. Copenhagen: The Danish Museum of Art \& Design, 2006.

- - - "Flemish Tapestry Workers in the Service of Nordic Kings." In Flemish Tapestry Weavers Abroad: Emigration and the Founding of Manufactories in Europe, edited by Guy Demarcel, 91-111. Leuven: Leuven University Press, 2002. Wood, Lucy. The Portraits of Anne of Denmark. Master's thesis, Courtauld Institute of Art, 1981.

${ }^{1}$ Relatively little is known about the artist. See Edward Town, "A Biographical Dictionary of London Painters, 1547-1625," The Volume of the Walpole Society 76 (2014): 1-235; Christopher Foley, "Somer [Someren], Paul [Pauwels] van," Grove Art Online, Oxford Art Online, last updated 2003, https://doi.org/10.1093/gao/9781884446054.article.T079700; Karen Hearn, "Somer, Paul [Pauwels] van [Paul Vansommer] (1577/8-1621/2), portrait painter," Oxford Dictionary of National Biography, last updated September 23, 2004, https:/doi.org/10.1093/ref:odnb/28107; Oliver Millar, "A Little Known Portrait by Paul Van Somer," The Burlington Magazine 92, no. 571 (1950): 294-96. An extended, bleached-looking copy of the portrait is at Lamport Hall in Northamptonshire. See Karen Hearn, "139. Anne of Denmark," in Dynasties: Painting in Tudor and Jacobean England 1530-1630, ed. Karen Hearn (London: Tate Gallery, 1995), 206-7. There is a version at Edinburgh Castle (full-length, standing, in a dark red interior, in hunting costume with two greyhounds), and another adaptation, probably painted by Jan van Belcamp for Charles I in the 1630s, including a third greyhound, now at Kinnaird Castle. Van Somer's design was woven in reverse by Francis Poyntz (1672) at Mortlake for a series of royal portraits reproduced in tapestry now at Houghton Hall. See H. Avray Tipping, English Homes Period V, vol. 1 (London: Country Life, 1921), 101; Thomas P. Campbell, "Continuity and Change in Tapestry Use and Design, 1680-1720," in Tapestry in the Baroque: Threads of Splendour, ed. Thomas P. Campbell (New Haven and London: Yale University Press, 2007), 493.

${ }^{2}$ The title of the portrait gives the sitter's name as "Anne," but she herself spelled her name "Anna." Anna will be used throughout to refer to the queen, whereas Anne will be retained for the title of the portrait.

${ }^{3}$ Jemma Field, "Anna of Denmark: A Late Portrait by Paul van Somer," The British Art Journal 18, no. 2 (2017): 50-56, and Wendy Hitchmough, "Setting' the Stuart Court: Placing Portraits in the 'Performance' of Anglo Spanish Negotiations," Journal of the History of Collections (February 2019): 1-20, HTTPS://DOI.ORG/10.1093/JHC/FHZ004. The 2019 quatercentenary of Anna's death has witnessed a renewed surge of interest in this intriguing consort. See the essays in Sara 
Ayres, ed., "The Northern Line: Representing Danish Consorts in Scotland, England and Great Britain," special issue, The Court Historian: The International Journal of Court Studies 24, no. 2 (August 2019), including Michael Pearce, "Anna of Denmark: Fashioning a Danish Court in Scotland," 138-51; Jemma Field, "Dressing a Queen: The Wardrobe of Anna of Denmark at the Scottish Court of King James VI, 1590-1603," 152-67, and Maureen Meikle, “Once a Dane, Always a Dane? Queen Anna of Denmark's Foreign Relations and Intercessions as a Queen Consort of Scotland and England, 1588-1619," 168-80. See also Jemma Field, "Anna of Denmark and the Politics of Religious Identity in Jacobean Scotland and England, c. 1592-1619," Northern Studies 50 (2019): 87-113; Jemma Field, "A 'Cipher of A and C Set on the One Syde with Diamonds': Anna of Denmark's Jewellery and the Politics of Dynastic Display," in Sartorial Politics in Early Modern Europe: Fashioning Women, ed. Erin Griffey (Amsterdam: Amsterdam University Press, 2019), 139-60; Wendy Hitchmough "Queenship and the Currency of Arts Patronage as Propaganda at the Early Stuart Court," in Royal Women and Dynastic Loyalty: Queenship and Power, eds., Caroline Dunn and Elizabeth Carney (Basingstoke, Hampshire: Palgrave Macmillan, 2018), 139-49; Catharine MacLeod, "Facing Europe: The Portraiture of Anne of Denmark (1579-1619)," in Telling Objects: Contextualizing the Role of the Consort in Early Modern Europe, eds., Jill Bepler and Svante Norrhem (Wiesbaden: Harrassowitz, 2018), 67-86; Anna Whitelock, "Reconsidering the Political Role of Anna of Denmark," in Queenship and Counsel in Early Modern Europe, ed. Helen Matheson-Pollock, Joanne Paul, and Catherine Fletcher (Basingstoke, Hampshire: Palgrave Macmillan, 2018), 237-58; Susan Dunn-Hensley, Anna of Denmark and Henrietta Maria: Virgins, Witches and Catholic Queens (Basingstoke, Hampshire: Palgrave Macmillan, 2017); Jemma Field, “The Wardrobe Goods of Anna of Denmark," Costume 51, no. 1 (2017): 3-27, https://doi. org/10.3366/cost.2017.0003; Sidia Fiorato, "Anna of Denmark and the Performance of the Queen Consort's Sovereignty," in Performing the Renaissance Body: Essays on Drama, Law and Representation, eds., Sidia Fiorato and John Drakakis (Berlin: De Gruyter, 2016), 247-72.

${ }^{4}$ Jemma Field notes that the portrait was later sent to Prince Charles at St. James's Palace on March 8, 1618, with a marginal notation in ESRO Glynde MS 320, fol.7r, reading "Sent to the prinz in St: Jaymes 8 Mar 1618." Field, “Anna of Denmark: A Late Portrait," 55n5. The same note is also quoted in Wendy Hitchmough as "sent to the prins to St. Jeymes 8 mch 1618." Hitchmough, "'Setting' the Stuart court," 20n122. In the same note, Hitchmough disputes the usual date given, 1618, stating that the "Stuart Calendar" means that this should be read as March 8, 1619; namely, a few days after the queen's death on March 2,1619. At this time the calendar year changed on March 25. See also Oliver Millar, The Tudor, Stuart and Early Georgian Pictures in the Collection of Her Majesty the Queen (London: Phaidon, 1963), 81; Lucy Wood, The Portraits of Anne of Denmark (master's thesis, Courtauld Institute of Art, 1981), 48.

${ }^{5}$ By the late 1630s, Anne of Denmark had moved to the Bear Gallery in Whitehall. See Millar, The Tudor, Stuart and Early Georgian Pictures, 16, 81. According to Abraham van der Doort's inventory, the portrait was, under the reign of Charles I, displayed in the Tennis Court Chamber in Whitehall, numbered 21. See Oliver Millar, ed., Abraham Van der Doort's Catalogue of the Collections of Charles I (London: Walpole Society, 1960), 5. By 1669, under Charles II, the copy by Jan van Belcamp (now at Kinnaird) was displayed in Hampton Court Palace, according to an unpublished diary in the British Library detailing Prince George of Denmark's Grand Tour to England in the summer of 1669. This suggests that the painting had lost none of its representative power or impact upon Anna's descendants during the intervening half century. In the entry for August 29: "Kong Jacob och Dronning Anne. Hun staar med haanden i siden, och i den anden 
haand en Kobbel steurehunde, 3 smaa hunde. De kalder hende Hunting Qveen. Princen har hendes Physiognomie" (King James and Queen Anne. She stands with one hand on her hip, and in the other hand a brace of greyhounds, three small dogs. They call her Hunting Queen. The prince has her physiognomy). My translation. British Library manuscripts Add MS 12487 and Add MS 12488, 18a. Miscatalogued as Journal of the Travels of the Crown Prince of Denmark, afterwards Christian V.

${ }^{6}$ Catriona Murray, Imaging Stuart Family Politics: Dynastic Crisis and Continuity (London: Routledge, 2017). Wolfram Martini and contributors have similarly examined hunting as a practice expressing elite distinction via an international, dynastic memory culture in Wolfram Martini, ed., Die Jagd der Eliten in der Erinnerungskulturen von der Antike bis in der Früher Neuzeit. Göttingen: Vandenhoeck und Ruprecht, 2000.

${ }^{7}$ For the gender of the "Renaissance elbow," see Joneath Spicer, "The Renaissance Elbow," in $A$ Cultural History of Gesture, eds., Jan Bremmer and Herman Roodenburg (Cambridge: Polity, 1991), 85; and Sheila ffoliot, "Catherine de' Medici as Artemisia: Figuring the Powerful Widow," in Rewriting the Renaissance: The Discourses of Sexual Difference in Early Modern Europe, ed. Margaret W. Ferguson, Maureen Quilligan, and Nancy J. Vickers (Chicago and London: University of Chicago, 1986), 233.

${ }^{8}$ Luc Duerloo, "The Hunt in the Performance of Archducal Rule: Endurance and Revival in the Habsburg Netherlands in the Early Seventeenth Century," Renaissance Quarterly 69 (2016): 116-54; Simon Adams, “The Queenes Majestie ... is now become a great huntress': Elizabeth I and the Chase," The Court Historian 18, no. 2 (2013): 143-64; Richard Almond, Daughters of Artemis: The Huntress in the Middle Ages and Renaissance (Cambridge: Brewer, 2009); Katharina Fietze, Im Gefolge Dianas: Frauen und Höfische Jagd im Mittelalter (1200-1500) (Cologne: Böhlau, 2005). Werner Rösener cites a number of noble women whose reputations as huntresses have survived. In the British context these include Queen Isabella, consort of Edward II of England; Queen Philippa of Hainault, consort of Edward III; Queen Anna of Bohemia; Queen Elisabeth I, and Mary Stuart. See Werner Rösener, Die Geschichte der Jagd (Dusseldorf and Zurich: Artemis and Winkler, 2004), 189-90. A fascinating, extended account of a hunt written by Infanta Isabella Clara Eugenia, sovereign of the Spanish Netherlands, can be found in Countess Marie Hennequin De Villermont, L'Infante Isabelle, Gouvernante des Pays-Bas (Paris: n.p., 1912), 62-65.

9 "I Chr. IV.s Skrivkalendar for 1607 anføres under 13 Sept.: Samme Dag blev min Gemahl skudt igjennem Kappe paa Jagten. Dronningen yndede baade Jagt og Ridning." Reported in E. F. S. Lund and C. Chr. Andersen, Dansk Malede Portroetter, vol 2.2 (Copenhagen: Gyldendal, 1897), 96. Also: "Sep. 13 Diesen Tag gieng ein Schuß auf der Jagd meiner Gemahlin durch die Kappe."

"König Christian des Vierten eigenhändige Anzeichnungen in seinem Schriebkalendar von 1607," in Johann Friedrich Schlegel, ed., Samlung zur Dänische Geschichte 3, no. 2 (Copenhagen: Sander und Schröder, 1776), 49.

10 "The Earl and Countess of Shrewsbury to the Earl of Salisbury. 23 August 1605," Calendar of the Manuscripts of the most Hon the Marquis of Salisbury, vol. 17, ed. M. S. Guiseppi (London: HMSO, 1938).

11 “John Chamberlain to Sir Dudley Carleton. 1 August 1613," State Papers Online: MS Secretaries of State: State Papers Domestic, James I, 1603-1640. SP 14/74 f.100. The National Archives of the UK.

12 “Thos. Watson to Lake, London. March 31 1617,"State Papers Online.

${ }^{13}$ The exhibition catalogue Frauen, Kunst und Macht: Drei Frauen aus dem Haus Habsburg, eds., 
Sabine Haag, Dagmar Eichberger and Annemarie Jordan Geschwend (Innsbruck: Schloss Ambras, 2018) reproduces portraits of female royal hunters, including a tapestry of Maria of Portugal on horseback bearing a falcon on her wrist (cat. 19) and a lost portrait of Maria of Hungary with a hunting dog and a hooded raptor (cat. 57). In the Wallace Collection there is a plaquette, Mary of Burgundy Hawking (ca. 1480), which shows its subject on horseback, bearing a raptor and accompanied by a dog (inv. S361). Jeremy Warren, The Wallace Collection Catalogue of Italian Sculpture, vol. 1 (London: Wallace Collection, 2016), 134-35. Mary of Burgundy famously met an early death while hunting, an event alluded to in the British Library manuscript in which a woman on horseback accompanied by two men and hunting dogs is pursued by skeletons in winding sheets. Book of Hours, ca. 1500, known as the "London Rothschild Hours" or "Hours of Joanna of Castile" Add MS 35313 f.158v. See also the Electress Sybille of Cleves, wife to John Frederick the Magnanimous, as portrayed in Lucas Cranach's Hunting near Hartenfels Castle (1540; Cleveland Museum of Art). Armed with a crossbow, she looks out at the spectator while preparing to fire on a deer who has been driven into the river. The narrative is fictional and does not document an actual event. See Stephan Selzer, "Jagdszenen aus Sachsen: Die Jagd als Höfische Fest auf Einem Tafelgemälde vom Ernestinischem Hof (1540)," in Mitteilungen der Residenzen-Kommission der Akademie der Wissenschaften zu Göttingen, Sonderheft 6, Höfische Feste im Spätmittelalter, eds., Gerhard Fouquet, Harm von Seggern and Gabriel Zeilinger (Kiel: Akademie Der Wissenschaften Zu Göttingen, 2003), 73-90.

${ }^{14}$ Brigitte Volk-Knüttel, Peter Candid (um 1548-1628): Gemälde, Zeichnungen, Druckgraphik (Berlin: Deutscher Verlag für Kunstwissenschaft, 2010); and Brigitte Volk-Knüttel, Wandteppiche für den Münchener Hof, nach Entwürfen von Peter Candid (Munich: Deutscher Kunstverlag, 1976).

${ }^{15}$ George Turbeville, The Noble Arte of Venerie or Hunting (London: n.p., 1575), 7. George Gascoigne translated Jacques du Fouilloux's La Venerie (1561) into English as The Noble Arte of Venerie or Hunting (1575) which was printed together with George Turberville's The Book of Falconrie or Hawking. Stephen Hamrick, "Set in Portraiture': George Gascoigne, Queen Elizabeth, and Adapting the Royal Image," Early Modern Literary Studies 11, no. 1 (May, 2005): 1-30, HTTP:// PURL.OCLC.ORG/EMLS/11-1/HAMRGASC.HTM.

${ }^{16}$ Adams, "The Queenes Majestie."

${ }^{17}$ George Wingfield Digby, assisted by Wendy Hefford, The Devonshire Hunting Tapestries (London: Victoria and Albert Museum, 1971).

${ }^{18}$ Susan Koslow, "Law and Order in Rubens's Wolf and Fox Hunt," The Art Bulletin 78, no. 4 (1996): 680-706. See also Birgit Franke, "Jagd und landesherrliche Domäne: Bilder höfischer Repräsentation in Spätmittelalter und Früher Neuzeit," in Martini, ed., Die Jagd der Eliten, 189-218.

${ }^{19}$ Such as the National Trust property Knole, in Kent. Ebeltje Hartkamp-Jonxis, Weaving Myths: Ovid's Metamorphoses and the Diana Tapestries in the Rijksmuseum (Amsterdam: Waanders, ca. 2009).

${ }^{20}$ Karen Hearn, "Peake, Robert (c. 1551-1619), portrait and decorative painter," Oxford Dictionary of National Biography, last updated September 23, 2004, HTTPS://DOI.ORG/10.1093/REF:OD$\mathrm{NB} / 21685$. A slightly later version of this composition, in which Robert Devereux, 3rd Earl of Essex, replaces Sir John Harington, is in the Royal Collection at Windsor Castle: Henry, Prince of Wales with Robert Devereux, 3rd Earl of Essex in the Hunting Field (ca. 1605). See also Millar, The Tudor, Stuart and Early Georgian Pictures, 30, 79. 
${ }^{21}$ Catharine MacLeod, Malcolm Smuts, and Timothy Wilks, eds., The Lost Prince: The Life \& Death of Henry Stuart (London: National Portrait Gallery, 2012), 59.

${ }^{22}$ Ulrik Reindel, "The King Tapestries at Kronborg Castle: A 'Mirror for Princes' for a Protestant Prince," in Portrait et Tapisserie/Portrait and Tapestry, eds., Philippe Bordes and Pascal-Francois Bertrand (Turnhout: Brepols, 2015), 71-87. See also Vibeke Woldbye, European Tapestries, 15th-20th Century (Copenhagen: The Danish Museum of Art \& Design, 2006).

${ }^{23}$ The first publication of the tapestries' verses, accompanied by woodcut portraits, was in Johan Francken, Chronica; Das ist: Beschreibung aller Könige in Dennemarcken / von dem Ersten Könige DAN: (welcher zur zeit des Königs Davidis regieret) biß auffChristianum den Vierdten dieses Namens ißt Regierenden und an der Zahl der hunderste (Magdeburg: n.p., 1597). Later, the engraver Albert Haelwegh published these with new engraved portraits in Regum Danioe Icones (Hafniæ: Georg Holst, 1648).

${ }^{24}$ Elizabeth Cleland, "1. Throne Baldachin," in Campbell, ed., Tapestry in the Baroque, 33.

${ }^{25}$ Alexander Marr, "Pregnant Wit: ingegno in Renaissance England," British Art Studies 1 (November 2015): HTTPS://DOI.ORG/10.17658/ISSN.2058-5462/ISSUE-01/AMARR.

${ }^{26}$ Stephen Greenblatt is the originator of the term. Stephen Greenblatt, Renaissance Self-Fashioning: from More to Shakespeare (1980; repr. Chicago: University of Chicago Press, 2005).

${ }^{27}$ Walter Liedtke, The Royal Horse and Rider (New York: Abaris, 1989), 256-57.

${ }^{28}$ Foley, "Somer [Someren], Paul [Pauwels] van."

${ }^{29}$ Thomas Allsen, The Royal Hunt in Eurasian History (Philadelphia: University of Pennsylvania Press, 2006).

${ }^{30}$ Anne Rooney gives a detailed bibliography in the introduction to her edition of The Tretysse off Huntyng (Brussels: Omirel, 1987).

${ }^{31}$ Aysha Pollnitz notes that in the month James succeeded to the English throne, between 13,000 and 16,000 copies of the text were printed in London and Edinburgh. Aysha Pollnitz, Princely Education in Early Modern Britain (Cambridge: Cambridge University Press, 2015), 318.

${ }^{32}$ For a detailed account of early modern English pedagogy and Henry and Charles's princely educations, see Pollnitz, 314-77; John Horden, "Peacham, Henry (b. 1578, d. in or after 1644), writer and illustrator," Oxford Dictionary of National Biography, last updated September 23, 2004, HTTPS://DOI.ORG/10.1093/REF:ODNB/21667.

${ }^{33}$ Part of The Institution of a Noble Young Man is dedicated to "Sr. Iohn Harington Sonn and heire." The dedication continues, "so I . . . haue cheifly intended this whole worke for your instructiõ, who doth profit as wel by good exãples, as by precepts, idq; Athenis, at the Princes Court," which suggests Cleland also worked as a tutor at the court of Prince Henry. James Cleland, Hērōpaideia or the Institution of a Young Noble Man (London: Joseph Barnes, 1622), 124.

${ }^{34}$ Cleland, Hèrō-paideia, 222-23.

${ }^{35}$ Henry Peacham, The Compleat Gentleman, Fashioning Him Absolute in the Most Necessary \& Commendable Qualities Concerning minde or Bodie that May Be Required in a Noble Gentleman (London: n.p., 1622), 218.

${ }^{36}$ Cleland, Hērō-paideia, 223.

${ }^{37}$ Cleland, Hērō-paideia, 223.

${ }^{38}$ Peacham, Compleat Gentleman, 22.

39 "Dieß geschicht aber allermeist in den vnvernunfftigen Thieren, welche mehr, als die Menschen vom Lufft regirt und verendert werden. Dann die Menschen haben ohn das etwas, das in sich hoher ist, welchs beide die Himlische und Elementarische Influentzias vbertrifft. Und wird der 
Mensch ubermits seiner vernunfft vnnd manigfaltigen gedancken, und außrichtungen, nicht so leichtlich daruon verwandelt vnd bewegt, gleich als die vnvernunfftigen Tier. Jedoch etliche Menchen mehr vnnd minder, als die andern." My translation. John Christianson and Tycho Brahe, "Tycho Brahe's Cosmology from the Astrologia of 1591," Isis 59, no. 3 (1968): 312-18. Brahe's close relationship with the royal doctor to Frederik II, Petrus Severinus, is analyzed in Jole Shackelford, "Providence, Power and Cosmic Causality in Early Modern Astronomy: The Case of Tycho Brahe and Petrus Severinus," in Tycho Brahe and Prague: Crossroads of European Science, ed. John R[obert]. Christianson (Frankfurt: Deutsch, 2002), 46-69. Petrus Severinus as the mediator of Paracelsus's ideas throughout Europe, and his role in disseminating these in Britain, is discussed in Jole Shackelford, A Philosophical Path for Paracelsian Medicine: The Ideas, Intellectual Context, and Influence of Petrus Severinus (1540/2-1602) (Copenhagen: Museum Tusculanum Press, 2004), especially "The Reception of Severinus' Theories in England," 250-85.

${ }^{40}$ Jonathan Gil Harris, Foreign Bodies and the Body Politic: Discourses of Social Pathology in Early Modern England (Cambridge: Cambridge University Press, 2006), 37.

${ }^{41}$ Anna's dogs are often described as Italian greyhounds. I have found no early modern references to this miniature breed within contemporaneous published and manuscript sources. There are, however, instances in which English black-and-white dogs are described in the cynegetic literature without a specific breed being designated. At this time, the qualities of dogs were more often detected in their colors, which denoted their humoral complexions, rather than by their "breeds," which is a modern term. See Jean Du Bec, Discours de l'Antagonie du Chien et du Lièvre (Paris: Librairie des Bibliophiles, 1880), reprinted from an original edition of 1593.

${ }^{42}$ Claude d'Anthenaise, Portraits en Costume de Chasse (Paris: Nicholas Chaudun, 2010), 128-31.

${ }^{43}$ Turbeville, The Noble Arte of Venerie or Hunting, 7.

44 "Les Anglois ont outre cela de trois sortes de chiens, les plus grands \& les plus beaux sont dits de race Royale, \& sont blancs marquetés de noir." My translation. Jacques Espée de Selincourt, Le Parfait Chasseur (Paris: Gabriel Quinet, 1683), 57.

${ }^{45}$ Thomas Elyot, The Boke Named the Gouernour, Deuysed by Syr Thomas Elyot, Knight (London: Tho. Bertheleti, 1537).

${ }^{46}$ Gervase Markham, The Gentlemans Academie OR The Booke of S Albans: by GM (London: n.p., 1595), 31-32.

${ }^{47}$ Edward Topsell, The Historie of Foure-footed Beastes ... Collected out of All the Volumes of C. Gesner, and All Other Writers to this Present Day (London: n.p., 1607), 266.

${ }^{48}$ Cleland, Hèrō-paideia, 74.

${ }^{49}$ John Robert Christianson, “The Hunt of King Frederik II of Denmark: Structures and Rituals," The Court Historian 18, no. 2 (2013): 181.

${ }^{50}$ Vibeke Woldbye, "Flemish Tapestry Workers in the Service of Nordic Kings," in Flemish Tapestry Weavers Abroad: Emigration and the Founding of Manufactories in Europe, ed. Guy Demarcel (Leuven: Leuven University Press, 2002), 94.

${ }^{51}$ Hans Belting, "Coat of Arms and the Portrait: Two Media of the Body," in An Anthropology of Images: Picture, Medium, Body (Princeton: Princeton University Press, 2011), 62-83.

${ }^{52}$ Belting, 80.

${ }^{53}$ Cleland, Hērō-paideia, 53-54.

${ }^{54}$ James VI and I, "Basilicon Doron," in King James VI and I: Political Writings, ed. Johan P. Somerville (Cambridge: Cambridge University Press, 1994), 35.

${ }^{55}$ Peacham, Compleat Gentleman, 44. 
${ }^{56}$ Michael Schoenfeldt, "Fables of the Belly in Early Modern England," in The Body in Parts: Fantasies of Corporeality in Early Modern England, ed. David Hillman and Carla Mazzio (New York and London: Routledge, 1997), 244.

${ }^{57}$ Denis Ribouillault, "Regurgitating Nature: On a Celebrated Anecdote by Karel van Mander about Pieter Bruegel the Elder," Journal of Historians of Netherlandish Art 8, no. 1 (Winter 2016) HTTPS://DOI.ORG/10.5092/JHNA.2016.8.1.4.

${ }^{58}$ Belting, An Anthropology of Images, 3.

${ }^{59}$ Gian Paolo Lomazzo, A Tracte Containing the Artes of Curious Paintinge, Caruinge \& Buildinge, The Second Booke, trans. Richard Haydocke (Oxford: n.p., 1598), 1-2.

${ }^{60}$ Thijs Weststeijn, The Visible World: Samuel van Hoogstraten's Art Theory and the Legitimation of Painting in the Dutch Golden Age (Amsterdam: Amsterdam University Press, 2008), 209.

${ }^{61}$ Aileen A. Feng, Writing Beloveds: Humanist Petrarchism and the Politics of Gender (Toronto: Toronto University Press, 2017), 136.

${ }^{62}$ Elizabeth Cropper, The Domenichino Affair: Novelty, Imitation, and Theft in Seventeenth-Century Rome (New Haven: Yale University Press, 2005), 102.

Recommended Citation:

Sara Ayres, "A Mirror for the Prince? Anne of Denmark in Hunting Costume with Her Dogs (1617) by Paul van Somer," Journal of Historians of Netherlandish Art 12:2 (Summer 2020) D0I: 10.5092/jhna.12.2.2 